\title{
TRABZON TAVANLI CAMİ HAZİRESİ 19. YÜZYIL KADIN MEZAR TAŞLARI*
}

\author{
Sevinç EREN $N^{* *}$
}

\section{$\ddot{O} z e t:$}

Millî kültürümüzün önemli bir parçasını teşkil eden mezar taşlarl ve mezarlıklarlmız geçmiş ile kurulan bağın nesiller boyu devam eden tanıklarıdır. Insanın ölümünden sonra onun hatırasını devam ettirmek için dikilen mezar taşları ve mezar yapıla$r l$, İslamiyet öncesi Türklerin sahip olduğu, atalar kültünden gelmektedir. İnsanoğlu geçmişten günümüze kendi kültürel birikimi doğrultusunda ölümü her zaman farkl şekillerde yorumlamıştır. Ölen insanlar için mezar yapısı üzerine taş dikmek binlerce yıldır devam eden bir geleneğin ürünüdür. Mezarların topluca bulunduğu açık alanlar şeklinde nitelendirilen mezarlıkların yanı sıra cami veya türbe avlusunda parmaklık ya da duvarlarla çevrili hazirelerde yer alan mezar taşları, ölünün gömüldüğ̈̈ yerin bilinmesi ve kimliğini göstermek amacıyla dikilmiştir. Mezar taşları yapıldıkları dönemin, çevrenin, inançların, geleneklerin, sanat anlayışının ortak ürünüdür ve tarihî birer belge olarak döneminin sanat anlayışını yansitır; unvanlar, isimler, meslek gruplarl, sülale isimleri, ölüm nedenleri gibi çeşitli konular hakkında somut bilgiler vermesi bakımından sosyo-kültürel açıdan da çok yönlü değerlere sahiptir. Osmanlı mezar taşları genel olarak Osmanlı Türkçesiyle yazılmıştır. Ancak erken tarihli mezar taşlarında Arapçanın da kullanıldı̆̆ı görülmektedir.

Çalışmada, sonuç olarak, Trabzon Tavanlı Cami Haziresinde yer alan 19. yüzyıla tarihlenen on dört adet kadın mezar taşı; malzeme, form, teknik, işleniş niteliği, bezeme özellikleri ile kitabe bilgileri bakımından tanıtılmış ve farklı bölgelerdeki Osmanlı mezar taşları karşılaştırılarak bu taşların Türk sanatı içindeki yeri belirlenmeye çalışılmıştır.

Anahtar kelime: Bezeme, mezar taşı, Trabzon, Tavanlı Cami, kadın mezar taşlarl.

\footnotetext{
Trabzon Gülbahar Hatun Camisi, Tavanlı Cami Haziresi ile Küçük Imaret Mezarlığı'ndaki Mezar Taşları adlı doktora tezinden üretilen bu makale "Milletlerarası Arap Harfli Mezar Taşları ve Yazıtları Çalıştayı”nda (27 Nisan-1 Mayıs 2016, Kosova- Prizren) sunulmuş bildiri metninin gözden geçirilmiş şeklidir.

** Dr. Öğr. Üyesi, Ordu Üniversitesi Fen Edebiyat Fakültesi Sanat Tarihi Bölümü, sevinceren@odu.edu.tr.
} 


\section{The 19th Century Women's Gravestones at the Graveyard of Trabzon Tavanlı Mosque}

\section{Abstract:}

As important parts of our national culture graves and gravestones are witnesses of relationships of past which goes on for generations. Gravestones and structure of graves, that continue the memory of men after death, comes from ancestor culture which pre-islamic Turks have. From past to present human being have commented death differently related to their own cultural background. That put a gravestone on grave for the dead is the production of a tradition which goes on for thousand years. Apart from graveyard, gravestones, which take place in mosque or shrine and a forbidden area surrounded with fences, were erected to know where inhumation is and show his/her identity. Graveyards are common products which reflect the period, environment, beliefs, traditions and understanding of art. Graveyards, apart from reflecting its own period containing understanding of art as historical sources, give concrete information about other subjects such as labels, names, jobs, family lines and causes of death and have versatile values with its rich contents in the point of sociocultural. The language used in Ottoman graveyards is generally Ottoman Turkish. However that usage of Arabian has been observed on graveyards of early periods.

In our study, fourteen women gravestones at the graveyard of Tavanl Mosque have been described in means of materials, forms, engraving techniques and adorment characteristics. Then it will be studied to determine their artistic characteristics and place in Turkish art by comparing with the other Ottoman gravestones.

Keywords: Decoration, gravestone, Trabzon, Tavanl Mosques, women, gravestone.

\section{Giriş}

Türk sanatının en küçük anıtları olarak daha önce yaşanmış hayatların, sosyo-kültürel olayların birer vesikası olan mezar taşları, tarihî birer belge olmalarının yanı sıra, ait oldukları dönemin sanat zevkini yansıtmaları açısından da ayrı bir kıymete sahiptir. Türklerde mezar geleneği Türk tarihinin başlangıcından bugüne kadar kesintisiz devam eden bir olgudur. Değişik dönemlerde birtakım farklılıklar arz eden bu gelenek genel hatlarıyla aynı inanışın devamlılı̆ğna bağlanabilir. ${ }^{1}$

Anıtsal yapılara göre daha çabuk ve daha kolay tahrip olan mezar taşları doğa faktörleri ve insan eliyle gerçekleştirilen tahribat sonucu her geçen gün

1 Türklerde mezar gelenekleri hakkında ayrıca bk. Gül Tunçel, “Türklerde Mezar Taşı Geleneğine Kısa Bir Bakış”, Bilge (1996/8), Ankara, 1996, s. 16-18; Yıldız Kocasavaş, "Eski Türkler'de Yas ve Ölü Gömme Âdetleri”, Türkler, C: III, Ankara, 2002, s. 67-75; Turgay Yazar, "Çadır- Bark-Türbe", Geçmişten Günümüze Mezarlık Kültürü ve Insan Hayatına Etkileri Sempozyumu, (18-20 Aralık 1998), İstanbul, 1999, s. 418-43; Alim, Karamürsel, "Türklerde Mezar Geleneği", Türkler, C: III, Ankara s. 240-243;, Yaşar Çoruhlu, "Kurgan ve Çadır” Çadır (Yurt)'dan Kümbet ve Türbeye Geçiş", Geçmişten Günümüze Mezarlık Kültürü ve Insan Hayatına Etkileri Sempozyumu (18-20 Aralık 1998), İstanbul, 1999, s. 49-50; Cengiz Alyılmaz, "Eski Türklerde Mezar Geleneği”, Defin, İstanbul, 2012, s. 179-188; H. Peter Laqueuer, Hüve'l-Baki, İstanbul'da Osmanlı Mezarlıklarl ve Mezar Taşları, İstanbul, 1997, s.1-6; Beyhan Karamağaralı; "Kültür Tarihimiz Bakımından Mezar Taşlarının Önemi ve İkonografisi” Geçmişten Günümüze Mezarlık Kültürü ve İnsan Hayatına Etkileri Sempozyumu (18-20 Aralık 1998), İstanbul 1999, s. 33-46. 
hızla yok olmaktadır. Bu sebeple konuya yönelik her çalışma, maddi manevi değerlerimizi yansıtan mezar taşlarının belgelenmesini sağlaması bakımından büyük önem taşımaktadır.

2009 ve 2011 yıllarında incelediğimiz Trabzon Tavanlı Cami Haziresinde yer alan mezar taşları, konunun oldukça kapsamlı olması sebebiyle sadece 19. yüzyıla tarihlenen kadın mezar taşları üzerinden değerlendirilmiştir. Çalışma kapsamında eserler fotoğraflarla belgelenerek ölçüleri alınmış, sonrasında mezar taşlarının kitabe metinleri okunmuştur. ${ }^{2}$ Mevcut hazirede 19. yüzyıla ait toplam 14 mezar tespit edilmiştir. Mezarlar, şahideli toprak mezarlar ve lahit biçimi şahideli mezarlar olmak üzere iki grupta ele alınmıştır³. Eserler kronolojik sıra gözetilerek form ${ }^{4}$, işleniş niteliği ve süsleme özellikleri bakımından ayrıntılı bir şekilde tanıtılmıştır. Mezar taşlarının kendi içinde benzerlik ve farklılıkları ortaya konularak, diğer bölgelerdeki Osmanlı mezar taşları ile karşılaştırılmış ve sanat tarihi içindeki yerleri belirlenmeye çalışılmıştır.

Trabzon Tavanlı Cami, Boztepe Caddesi, Gazi Paşa Mahallesi, Tavanlı Cami Sokak'ta bulunmaktadır. Cami H 1291/ M 1874 yılında yaptırılmıştır. 1890 yılında bir onarım görmüştür (Tuluk-Düzenli 2010: 75-76). ${ }^{5}$ 2010-2011 yılları arasında Vakıflar Genel Müdürlüğü tarafından restore edilmiştir. Kesme taş malzeme ile inşa edilen cami, kuzey güney yönünde dikdörtgen planlıdır. Harim ve üç bölümlü son cemaat yerinden oluşan eser ahşap tavanlı, dıştan kırma çatıyla örtülüdür. Son cemaat yerinin kuzey batısında sekizgen kaideli minaresi bulunmaktadır. Tavanlı Cami'nin batı ve güney yanlarında duvarla çevrili büyük bir haziresi bulunmaktadır (F.1).

\section{I-Şahideli Toprak Mezarlar}

Taş No.1: Plaka görünümünde, yukarı doğru hafifçe genişleyen mermer başucu taşı ${ }^{6}$ üçgen bir tepelikle taçlandırılmıştır. Üçgen tepeliğin eksenine or-

2 Mezar taşlarının kitabe metinlerini okuyan Sayın Pof. Dr. Abdulkadir Dündar'a teşekkürlerimi sunarım.

Bazı taşların bir bölümü toprağa derince gömülü olduğundan satırların bir kısmı ne yazık ki okunamamıştır. Mezar taşlarının okunamayan satırları için Murat Yüksel'in, Trabzon'da Türk Islam Eserleri ve Kitabeleri (2. Baskı) Trabzon 2000 adlı yayınında verdiği bilgilerden istifade edilmiştir.

3 Mezar ve mezar taşlarının tipolojik tasnifleri için bk. Gül Tunçel, "Üsküp Alaca Cami Haziresi’ndeki Şahideler”, Hacettepe Üniversitesi Edebiyat Fakültesi Dergisi, C: 22, S: 1, Ankara, 2005 c, s. 226-230; Gül, Tunçel, "Beypazarı Müzesindeki Mezar Taşları”, Hacettepe Üniversitesi, Edebiyat Fakültesi, Sanat Tarihi Ortaçă̆'da Anadolu, Prof. Dr. Aynur Durukan'a Armağan, Ankara 2002, s. 441-456; Halit Çal, Kastamonu Atabey Gazi Camisi ve Türbesi Hazirelerindeki Mezar Taşları, Ankara, 2008a, s. 3-11; Halit Çal, “Ah Mine'l-Mevt/Kastamonu Şehrindeki 14.-20. Yüzyıl Mezar ve Mezar Taşları”, Üsküdar 'a Kadar” Kastamonu. İstanbul, 2008b, s. 356-358; Sevinç Eren, ” Trabzon Gülbahar Hatun Camisi, Tavanlı Cami Haziresi ile Küçük Imaret Mezarlı̆̆ı'ndaki Mezar Taşları”, Yayımlanmamış doktora tezi, Gazi Üniversitesi, Ankara, 2011.

4 Form itibarıyla ise, plaka görünüşlü mezar taşlarının ölçüleri, yükseklik, üst genişlik, alt genişlik ve taş kalınlığı; başlıklarda yükseklik, üst çevre, alt çevre; boyun bölümünde ise yükseklik ve çevre ölçüsü sıralamasıyla verilmiştir.

5 Konuyla ilgili ayrıca bk. Ömer Kahraman “Trabzon'da Türk Devri Mimar Eserleri”, Yayımlanmamış yüksek lisans tezi. Atatürk Üniversitesi, Erzurum, 2003, s.120; Haşim Karpuz, "Trabzon İl Merkezi ve İlçelerindeki Önemli Tarihi Yapılar”, Trabzon, Ankara, 1996 s.119; Murat Yüksel, Trabzon'da Türk İslam Eserleri ve Kitabeler, C: I, Trabzon, 2000, s.146.

6 Başucu taş1: 150x48-42x13 cm. 
tası inci tanesi dolgulu, iki yan kenarı uçları volütlü "C" kıvrımlarıyla sınırlı, üçer dilimli akant yapraklarının oluşturduğu bezeme yüzeyden kabartılmıştır. İstiridye motifi gibi görülen bu bezemenin her iki yanına simetrik olarak işlenmiş ince bir dal üzerinde yer alan gül ve goncası zarif bir şekilde yerleştirilmiştir. Tepeliğin zirve kısmına yerleştirilen üçer dilimli altı yapraktan oluşan demet ile eksendeki motif taçlandırılmıştır. Tepeliğin kalan yüzeyi uçları volütlü C kıvrımlarıyla simetrik bir biçimde doldurulmuştur. Gövde ve tepelik arası ince, düz yüzeyli silmelerle oluşturulan kalın kuşağın, iki yanı birer lale çiçeğiyle nihayetlendirilmiştir. Kuşağın yüzeyi, ortası dolgulu, etrafı stilize yapraklardan oluşan oval formda üç kartuşla bezenmiştir. Kitabe gövdesinin üst kısmı basık kemer formunda bitkisel bir düzenleme ile sınırlandırılmıştır. Gövdenin üst kısmının iki köşesine de tepelik kısmında olduğu gibi birer zarif gül dalı yerleştirilmiştir (F.2a). Kitabe metni ince silmelerle oluşturulan panolar içinde on iki satır hâlinde celi sülüs hatla kabartılmıştır.

Kitabe metninin Latin harfleriyle yazılışı şu şekildedir:

Hüve'l-Hallâkü'l bâki

Bu fenâdan çekdim el-çün ömrüm irdi ...

Vuslat-ı dar-ı bekâ mâder birâder ...

Emr-i rabbani ezelden böyle hâlinde kalmaz ...

el hükmüllillah vâdi sâadet

Cefa olmaz bende mesken eylerim haktan bî-mekân

... maksudu muradım irgüre hâcât ...

Nemli-zâde Osman Ăga'nın validesi merhume

Ve mağfûrun leha Fâtıma Hatun

Ruhuna rıaen lillâhi el-Fatihâ

Sene 1217 (M.1802)

Mermer malzeme ile yapılan yukarı doğru genişleyen plaka gövdeli aya$\mathrm{kucu}^{7}$ taşı üçgen bir tepelikle taçlandırılmıştır. Gövdenin taş kenarları ve tepelik kısmı ince düz bir silmeyle sınırlandırılmıştır. Eksene bütün taş yüzeyini kaplayacak biçimde bir hurma ağacı yerleştirilmiştir. Ağacın gövdesi kazıma çizgilerle oluşturulan üst üstte sıralanmış eşkenar dörtgenlerle belirginleştirilmiştir. Şerit biçimindeki iri hurma yaprakları altta üçerli gruplar hâlinde uçları aşağı sarkar biçimde işlenmiştir. Üstte tepelik kısmının yüzeyinde ise beş hurma yaprağ tepe noktasında lale oluşturacak biçimde daralarak simetrik bir anlayışla sağlı sollu yerleştirilmiştir (F.2b).

7 Ayakucu taş1: $85 \times 35-32 \times 8 \mathrm{~cm}$. 
Taş No.2: Yukarı doğru genişleyen başucu taşının, plaka biçimindeki gövdesi üçgen bir tepelikle taçlandırılmıştır ${ }^{8}$. Tepelik eksenine ayaklı, yayvan gövdeli, geniş ağızlı bir meyve kâsesi yerleştirilmiştir. İçinde üç üzüm salkımı bulunan kâsenin çevresi iri akant yapraklarıyla taçlandırılmıştır. Gövde taş kenarlarından bitkisel başlıklı sütuncelerle üstten ise yuvarlak kemer formunda bir silmeyle kuşatılmıştır. Kemer formunun üst kısmı akant yapraklarının oluşturduğu bezemeyle taçlandırılmıştır (F.3a). Kitabe metni yatay şeritlerle oluşturulan panolar içine yedi satır olarak sülüs hatla kabartılmıştır.

Kitabe metninin Latin harfleriyle yazılışı şu şekildedir:

Hüve'l-Bâki

Beni kıl mağfiret ey Rabb-i Yezdân

Bi-hakkı arş-ı a'zam nûr-ı Kur'ân

Gelüp kabrim ziyaret eyleyen ihvân

Edeler rûhuma bir Fâtiha ihsân

Ahmed Çavuş-zade Hasan

A ğa'nın kerimesi merhûme Rukiye...'

Aynı malzemeyle yapılan ayakucu taşının paralel kenarlarla yükselen plaka biçimindeki gövdesi ${ }^{10}$ üç dilimli kemer formuyla taçlandırılmıştır ve gövde yüzeyi süslemeye yer verilmemiştir (F.3b).

Taş No.3: Mermer başucu taşının paralel kenarlarla yükselen plaka biçimli gövdesi ${ }^{11}$ silindirik bir boyunla daralarak, fes ya da takke görünümünde bir başlıkla taçlandırılmıştır. Yukarıdan aşağı doğru genişleyerek, kazıma çizgilerle üç bölüme ayrılan başlığın alt kısmı, stilize yapraklarla bezenmiştir. İnce silindirik boynun üst bölümünde stilize yapraklar, yukarı doğru uzanarak devam eder. Altta ise içleri yaprak dolgulu sağa ve sola eğimli silmelerin üstte birleşmesiyle oluşan gerdanlık motifinin ortasından yuvarlak bir form aşağ 1 doğru sarkıtılmıştır. Gövde taş kenarlarından ince düz, üstten yarım daire formlu kemerle taçlandırılarak köşelere birer lale çiçeği yerleştirilmiştir. Kitabe metni yatay şeritlerle oluşturulan panolar içine on bir satır hâlinde celi sülüs hatla kabartılmıştır. Başlangıç ifadesi tuğra biçiminde kabartılarak yarım daire kemer formu ile çevrelenmiştir (F.4a).

8 Başucu taş1: 90x35-32 $\times 10 \mathrm{~cm}$.

9 Hatun ruhuna Fatiha.

Sene 1218 (M.1803), Murat Yüksel, Trabzon'da Türk İslam Eserleri, C: II. s. 211.

10 Ayakucu taş1: $73 \times 31-31 \times 10 \mathrm{~cm}$.

11 Başucu taş1: 150x34-34x14 cm. Başlık: 14x36-85 cm. Boyun: $21 \times 41 \mathrm{~cm}$. 
Kitabe metninin Latin harfleriyle yazılışı şu şekildedir:

Şefâ' 'ati li'ehlil-kebâiri min ümmetî

Mürg-ı dil uçdu kafesten cân pâresi

Kondu cennet bă̆ına dilde kald y yâresi

Hey meded bulunmadı vebâ emrâzının çâresi

Genç yaşında meğer tekmil imiş va'desi

Gel şu mevtâ kabrine oku bir Fâtiha sûr

Ey felek layık mıdır türâb olsun lânesi

Şâtır-zâde Mir'alay Hurşîd İbrahim

A ̆ga'nın zevcesi Kuğu-zâde kerimesi

\section{Merhûme Esma Hanım ruhuna el-Fatihâ}

Sene 1221(M.1806)

Aynı malzemeyle yapılan, ayakucu taşının paralel kenarlı plaka biçimindeki gövdesi ${ }^{12}$ iki kademeli soğan görünümünde bir başlıkla taçlandırılmıştır. Başlığın kubbemsi üst bölümü iç bükey kıvrımlarla daralarak oval, dışa taşkın alt bölümüne birleşmiştir. İki kısım birbirinden ince bir silmeyle ayrılmıştır. Başlığın yüzeyinde bezeme unsuru görülmemektedir.

Gövde taş kenarlarından ince silmelerle kuşatılmıştır. Eksene yerleştirilen servi ağacı motifi yukarı doğru daralarak devam etmektedir. Ağacın gövdesi üçlü yaprak düzenlemeleriyle belirginleştirilmiştir. Selvi ağacına sarılan asma dalı silmelerle yüzeyde üç yuvarlak madalyon biçiminde işlenmiştir. Selvi ağacına sarılı dallar arasında altı üzüm salkımı filizleri ve yapraklarıyla simetrik bir şekilde stilize edilerek kabartılmıştır. Gövde üstten dilimli kemer formunda bir silmeyle kuşatılmıştır (F.4b).

Taş No.4: Mermer malzeme ile yapılmış başucu taş ${ }^{13}$ yukarıya doğru genişleyerek üçgen şeklinde tepelikle sonlandırılmıştır. Tepelik alınlığı bezemesizdir. Kitabe metni, yatay düz silmelerle ayrılan panolara, sekiz satır hâlinde celi sülüs hatla kabartılmıştır. Gövdede yazı dışında dekoratif nitelikte süs unsuru bulunmamaktadır (F.5a).

Kitabe metninin Latin harfleriyle yazılışı şu şekildedir:

Yâ İlahi ol mübârek ism-i pâkin izzeti

Hem Resûlün fahr-i âlem Şâh-ı kevneyn hürmeti

Eyle kabrin ravza-i cennet ya Ilâhe'l âlemin

Gece gündüz eylesünler huriler hizmeti

12 Ayakucu taş1: $150 \times 28-28 \times 12 \mathrm{~cm}$.

13 Başucu taş1: $120 \times 38-34 \times 10 \mathrm{~cm}$. 


\section{Merhûm Hacı Mustafâ Ăga'nın}

Kerîmesi merhûme Fâtıma Hatun'un

\section{Ruhuna Fâtiha}

Sene 1222 (M.1807)

Ayakucu taşının aşağıdan yukarıya doğru hafifçe genişleyerek yükselen plaka biçiminde bir gövdesi ${ }^{14}$ sivri kemer formunda tepelikle taçlandırılmıştır. Uçları spiral döngülü ' $S$ ' biçimli kıvrım dallar taşın tüm yüzeyini kaplamaktadır (F.5b).

Taş No.5: Paralel kenarlarla uzanan plaka biçimindeki mermer başucu taş $1{ }^{15}$ ince bir boyunla daralarak takke ya da fes görünümündeki başlıkla taçlandırılmıştır (F.6a). Başlığın üst kısmına daire formlu basık koni biçiminde tepelik tarzı bir aksesuar (F.6b) yerleştirilmiştir. ${ }^{16}$ Yukarıdan aşağıya doğru genişleyen başlık yüzeyi kazıma çizgilerle üç bölüme ayrılmıştır. Tamamen kitabe metnine ayrılan gövde taş kenarlarından ince düz silmelerle kuşatılmıştır. Gövde sağa eğimli şeritlerle panolara ayrılarak yazı dokuz satır hâlinde celi sülüs hatla kabartılmıştır.

Kitabe metninin Latin harfleriyle yazılışı şu şekildedir:

Hüve'l-Hallâk'ül-Bâki

Yürü ey bî-vefâ dünyâ seninle el-vedâ olsun

İsi cevr cefâ dünyâ seninle el-vedâ olsun

Fenâdan elçeküb Yâ Rab bakâya eyledim rihlet

Kerem kul cürmümü afv et Adn bana makâm olsun

Ilâhi ben günâhkârı haşırda eyleme rüsvây

Dilerim cürm ü isyânım senin afvinla mahv olsun

El-Hac Abdü'l-Gâfur Efendi karındaşı Hâfiz

Osman Efendi halilesi merhûme ve mağfûre...$^{17}$

Mermer malzemeyle yapılan ayakucu taşının büyük bölümü toprak altındadır. Mevcut durumuna göre yukarı doğru hafifçe genişleyen plaka gövde ${ }^{18}$ sivri kemer formunda bir tepelikle taçlandırılmıştır. Gövde üsten uçları volütlü 'C' kıvrımlı silmelerle oluşturulan dekoratif bir kemerle sınırlandırılmıştır. Üst bölümü görülen gövde yüzeyine selvi ağacı motifi yerleştirilmiştir (F.6c).

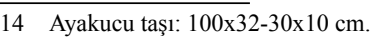

15 Başucu taş1: 99x28-28x12 cm. Başlık: 14x28-72 cm Boyun: 8x33 cm.

16 bk.: M. Reşat Sümerkan, Trabzon Yöresi Geleneksel El Sanatları, Trabzon, 1998, s.140-141.

17 El-Muhtac İlâ Rahmeti Rabbihi'l-Gafûr.

Sâliha Hanım ruhiçün rızâen lillâhi Fatiha.

Sene 1244(M.1828), Murat Yüksel Trabzon'da Türk Islam Eserleri C: II. s. 228.

18 Ayakucu taş1: 63×32-30x9 cm. 
Taş No.6: Mermer başucu taşının paralel kenarlı plaka biçimindeki gövdesi ${ }^{19}$ silindirik formda iki kademeli bir boyunla daralarak takke ya da fes görünümündeki başlıkla taçlandırılmıştır. Başlığın üst kısmına daire formlu basık koni biçiminde tepelik tarzı bir aksesuar yerleştirilmiştir. Yukarıdan aşağ1 doğru genişleyen başlık kazıma çizgilerle üç bölüme ayrılmıştır. Boynun üst eksenine yüzeyden dışa taşkın bir kabara motifi yerleştirilmiştir. Tamamen kitabe metnine ayrılan gövde taş kenarlarından ince düz silmelerle sınırlandırılmıştır (F.7). Yazı yatay şeritlerle oluşturulan panolar içine yedi satır hâlinde celi sülüs hatla kabartılmıştır.

Kitabe metninin Latin harfleriyle yazılışı şu şekildedir:

Hüve'l-Bâki

El-merhûm el-măgfûr İâ rahmeti

Rabbihi'l-Gafûr Temelli

Zâde Salih Ă̆a'nın

Kerimesi Gül Hanım

Ruhuna el-Fâtiha

Fi 11 B Receb Sene 1251 M.2 Kasim 1835)

Taş No.7: Mermer malzemenin kullanıldığı başucu taşının plaka şeklindeki gövdesi ${ }^{20}$ yukarı genişleyerek bitkisel tepelikle taçlandırılmıştır. Tepelik bölümünde eksene, ortasında altı yapraklı bir çiçek motifi bulunan ve yukarı doğru genişleyen bereket boynuzu formunda bir vazo kabartılarak işlenmiştir. Gövde taş kenarlarından S biçimli profillerle üstten ise dilimli kemer formuyla çerçevelenmiştir. Kitabe metni yatay şeritlerle oluşturulan panolar içine yedi satır hâlinde celi talik hatla yazılmıştır (F.8a).

Kitabe metninin Latin harfleriyle yazılışı şu şekildedir:

Hüve'l-Hayyu'l-Bâki

Bâki-zâde Hâfiz Ahmed Rif'ât'in menkûhası

........ledin yakdın evlâdın bu nâra âh felek

hamlini vaz'etdiği rahmet dahi def'olmadan

Cân-gâhin eyledin tebdîl-i mezâra âh felek

Gerçi sen bir cân sundun câm-ı mevti cevrile

Çok ciğerler kıldın ammâ pâre pâre âh felek... ${ }^{21}$

19 Başucu taşı: 84x21-21x12 cm. Başlik: 7x23-46 cm. Boyun: 8x28 cm.

20 Başucu taş1: $95 \times 38-36 \times 8 \mathrm{~cm}$.

21 Hak anı bahş eyledi bint-i Resûl-î ekrem'e

Sen yine kaldın eli boş yüzü kara âh felek

Rahmet ile yâd edüb Zühdî dedi târîh-î tâm

Göçdü dünyadan Rakûş Hânım ne çâre âh felek

Sene, 1267 (M.1850)

Rızâen lillâhi Fâtihâ 7 C, Murat Yüksel, Trabzon'da Türk İslam Eserleri, C: II, s. 233-234. 
Ayakucu taş ${ }^{22}$ yukarı doğru hafifçe genişleyerek yükselen plaka şeklinde bir gövdeye sahiptir. Gövde üçgen tepelikte taçlanmıştır. Gövdeden iki yatay profil arasına yerleştirilen dendan motiflerinden oluşan bir bordürle tepelik kısmına geçilmiştir. Üst kısmı kırık olan tepeliğin eksenine sathi üç silmeyle boğum oluşturularak, stilize bir palmet motifi yerleştirilmiştir (F.8b).

Taş No.8: Mermer başucu taşının yukarı doğru hafifçe genişleyen plaka biçimindeki gövdesi ${ }^{23}$ bitkisel tepelikle taçlandırılmıştır. Dıştan kemer formu oluşturan tepelik yüzeyine, üst üste dizilmiş uçları aşağı sarkan yapraklar kademeli biçimde yerleştirilmiştir. Yapraklar arasına katmerli üç gül motifi aşağı, sağa ve sola dönük biçimde yüzeyden yüksekçe kabartılarak işlenmiştir. Gövde, çift kademeli silmelerle sınırlandırılan mine çiçeği ve kıvrımlı yapraklardan oluşan bordürle oval bir çerçeve ile kuşatılmıştır. Kitabenin üst köşeleri karş1lıklı birer gül dalıyla bezenmiş̧tir (F.9). Kitabe metni sağa meyilli silmelerle oluşturulan panolar içine on altı satır hâlinde celi talik hatla kabartılmıştır.

Kitabe metninin Latin harfleriyle yazılışı şu şekildedir:

Âh mine'l-mevt

Hafid-i Şatır-oğlu Mir Vâhid zevcesi ya'ni

Hâfize Hanım işte terk-i dünyâ eyledi nâ' 'gâh

Reside olmadan hadd-i kemâle bâğ-ı âlemde

Şikest etti nihâl-i ömrünü bâd-ı ecel sad âh

Ne dem ki zîr-i hâke defn olundu ol sadef-trynet

Yetim kaldı cihânda bir iki dür-dânesi eyvah

Aceb bir gevher-i gencine-i ismet idi zâtı

Garik-i lücce-i gufrân-u rahmet eylesün Allah

Bâkada nâil-i zevk u safâ oldukça Merhûme

Săg olsun hem-ser-i mîr-i uluvvü'l-himmeti her gâh

Bu bir emr-i İlâhîdir sabırdan gayri yok çâre

Edersen hasretiyle haşre dek bin nâle-i cân-gâh

Gelüb bir ehl-i cennet fevtine Âgâh dedi tarih

Hâfize sahn-ı Adn-i eyledi ukbâda cevlân-gâh

Fâtiha 1276(M.1859)

Taş No.9: Yukarı doğru hafifçe genişleyen mermer başucu taşının plaka biçimindeki gövdesi ${ }^{24}$ bitkisel tepelikle taçlandırılmıştır. Tepelik karşılıklı

22 Ayakucu taş1: $75 \times 36-34 \times 5 \mathrm{~cm}$.

23 Başucu taşı: 162x33-30x9 cm.

24 Başucu taş: 140x 33-30x11 cm. 
sağa ve sola uzanan ve dört daldan gelişen sivri uçlu yaprakların hacimli bir biçimde taş yüzeyine işlenmesiyle oluşturulmuştur. Yapraklar arasına piramidal düzende beş iri gül motifi simetrik olarak yerleştirilmiştir. Boyun kısmı enli bir kuşakla bağlanmış ve ortadaki daha büyük, yanlara doğru küçülerek devam eden on iki daire motifinden oluşan beşi bir yerde türü gerdanlıkla bezenmiştir. Gövde taş kenarlarından kalın, üsten ise üç dilimli kemer formuyla sınırlandırılmıştır. Kitabe metni sağa eğimli şeritlerle oluşturulan panolar içine on bir satır hâlinde celi talik hatla kabartılmışıtır (F.10).

Kitabe metninin Latin harfleriyle yazılışı şu şekildedir:

Hüve'l-Bâki

Sınıf-ı askerden mülazım şol Ahmed es-Seyyidinin

Zevce-i men-kuhası bir iffet-i âcizâne

Gençliğinde fevt olup hubb-ı kavileri nemsubatini

Firkatleriyle ne âl-ü gamdan ila yevmi'd-dâr

Sinin-i hayfa kim yirmi üç iken yek ecel

Hakk-ı emr iruşub geldi âna âhir-î mihâd

Gelüp kabrin ziyaret eyleyen ihvan-ı din

Eylesünler ruhu pakin it rahmetle yâd

... ah idüp tarih-i ......

.... Bekâ oldu ...

Sene 1300(M.1882)

Taş No.10: Yukarı doğru hafifçe genişleyen mermer başucu taşının plaka biçimindeki gövdesi ${ }^{25}$, iri bir yıldız motifiyle taçlandırılmıştır. Tepelik yüzeyine ortası beş yapraklı çiçek motifiyle dolgulu on üç kollu yıldız motifi kabartılarak işlenmiştir. Yıldız motifi her iki yandan dışa doğru kıvrımlı iri birer yaprakla gövde kısmına birleştirilmiştir. Gövde taş kenarlarından düz, üstten dilimli kemer formunda silmelerle sınırlandırılmıştır. Kitabe metni sağa eğimli silmelerle oluşturulan panolar içine dokuz satır hâlinde celi talik hatla kabartılmıştır (F.11).

Kitabe metninin Latin harfleriyle yazılışı şu şekildedir:

Âh Mine'l-Mevt

Zâir düsün de âkibet-i hâl-iâlemi

Gaflete bakma Fâtiha ssı geçme el-amân

Hâmûş olub şu kabrin içinde yatan dahi

Söyler güler gezerdi senin gibi bir zaman

25 Başucu taş1: $105 \times 28-26 \times 7 \mathrm{~cm}$. 
Mîr-alay izzetlû Mehmed Hasîb

Bey Efendi'nin validesi

Merhûme Fâtıma Hanım'in ruhuna

Rızaen lillâhi Te'ala'l-Fâtiha ... ${ }^{26}$

\section{II. Şahideli Lahit Biçimli Mezarlar ${ }^{27}$}

Taş No.11: Dikdörtgen prizması formunda lahit mezar ${ }^{28}$, baş ve ayakucu taşından oluşmaktadır (F.12a). Lahitin alt bölümü kesme taş, dikdörtgen levha biçimindeki kapak taşı ise mermer malzeme ile yapılmıştır. Kademeli olarak profillendirilen kapak taşı üzerinde oval bir açıklık bulunmaktadır. Lahitin yüzeyi bezemesizdir.

Plaka gövdeli bitkisel bir tepelikli mermer baş taşı $\operatorname{armudi}^{29}$ formda aşağ doğru genişleyerek sonlandırılmıştır. Tepelik yüzeyine, buket biçiminde üst üste konulan yapraklar arasına, alta iri üç gül motifi, üste ise daha küçük iki hatmi çiçeği yerleştirilmiştir. Boyun, ince bir silme ile boğum oluşturularak, iki kazıma çizgiyle belirginleştirilmiştir. Aşağı sarkan kıvrık yaprakların ortası kabara motifiyle dolgulanmıştır. "S" kıvrımlı grift akant yaprakları arasına ikişerli ve üçerli yerleştirilen gül motiflerinden oluşan bezeme ile gövde kenarları iki yandan sınırlandırılmıştır. Kitabenin ilk satırına kadar uzanan, yapraklardan oluşan girland motifinin ortası katmerli bir gülle bezenmiştir. Girland motifinin başlangıç köşeleri kordon gibi düğümlenerek işlenmiştir. Gövdenin alt kısmı, C kıvrımlı dallarla sınırlanan ortasında stilize palmet motifinin yer aldığı bir kaide ile lahit üzerine yerleştirilmiştir. Bezemeler yüzeyden oldukça yüksek kabartılarak dışa taşkın plastik bir görünümde verilmiştir (F.12b). Kitabe metni yatay silmelerle oluşturulan panolar içine yedi satır hâlinde celi sülüs hatla kabartılmıştır.

Kitabe metninin Latin harfleriyle yazılışı şu şekildedir:

Âh Mine'l-Mevt Hüve'l-Hallakü'l-Baki

Trabzon eşrafindan

Ve mütehayyizân-I tüccârandan Nemli

Zâde el-Hâc Mahmûd Efendi'nin

Kerime-i güzin muhterimesi Fâike Hanım

Ruhu mahsumelerine rizaen li'llahil Fâtiha

Fi 21 Rebiül'sânî sene 1303 (M. 27 ocak1885)

26 Sene 1311(M.1893), Murat Yüksel, Trabzon'da Türk İslam Eserleri C: II. s. 256.

27 Lahit biçimi mezarların ölçüleri yükseklik, en ve boy sıralamasıyla verilmiştir.

28 Lahit biçimi mezar ölçüleri: $51 \times 63 \times 140 \mathrm{~cm}$.

29 Başucu taşı: $128 \times 37-47 \times 11 \mathrm{~cm}$. 
Mermer malzemeyle yapılan ayakucu taş1 ${ }^{30}$ başucu taşıyla aynı form ve bezemeye sahiptir. Aşağı doğru hafifçe genişleyen plaka biçimindeki gövde, bitkisel tepelikle taçlanmıştır. Üst üste akant yapraklarının kademeli olarak s1ralanmasiyla oluşturulan kemer formunun yüzeyine aşağ 1 , sağa ve sola bakan üç iri gül motifi ve iki hatmi çiçeği kabartılmıştır. Gövdenin eksenine ucu çatallı bir daldan gelişen fiyonk motifiyle bağlanmış asma dalı yerleştirilmiştir. Fiyonk motifinin halkaları, ucundan yukarı ve aşağıya doğru uzanan kurdelelerin ortasına birer lale yerleştirilmiştir. Stilize edilerek işlenen asma dalı yaprakları, üzüm salkımı ve uçları döngülü filizleri ile taş yüzeyine kabartılmıştır.

Taş No.12: Dikdörtgen prizması biçimindeki lahit ${ }^{31}$ mezar başucu ve ayakucu taşından oluşmaktadır (F.13a). Lahitin gövdesi kesme taş, kapak taşı ise mermer malzeme ile yapılmıştır. Profillerle kuşatılan dikdörtgen levha biçimindeki kapak taşı üzerinde yuvarlak bir boşluk mevcuttur.

Plaka gövdeli mermer başucu taşı bitkisel tepelikle taçlanarak, armudi

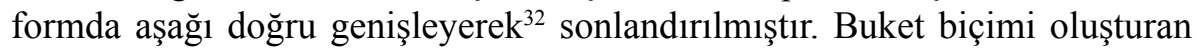
tepelik yüzeyine üst üstte konumlandırılmış yapraklar arasında alta iri üç gül motifi, üste ise daha küçük iki hatmi çiçeği yerleştirilmiştir. Dilimli akant yapraklarından oluşan boyun, ince bir silme ile boğum oluşturmuştur. Kitabenin ilk satırına kadar uzanan, yapraklardan oluşan girland motifinin ortası katmerli bir gülle bezenmiştir. Gövdenin alt kısmı, C kıvrımlı dallarla sınırlanan stilize palmet motifinin oluşturduğu bezeme ile nihayetlenmiştir. Bezemeler yüzeyden oldukça yüksek kabartılarak dışa taşkın plastik bir görünümde verilmiştir (F.13b). Kitabe metni yatay silmelerle oluşturulan panolar içine sekiz satır hâlinde celi sülüs hatla kabartılmıştır.

Kitabe metninin Latin harfleriyle yazılışı şu şekildedir:

Hüve'l-Bâki

Hân Ăgası Tâhir

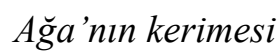

Nemli-zâde Ahmed

Efendi'nin refika-i

Muhteremesi Habibe

Hanımın ruhiçün el-Fatihâ

Sene 1307 Zilkade (M. Haziran/Temmuz 1890

Mermer malzemeyle yapılan ayakucu taş1 $1^{33}$, başucu taşıyla aynı form ve bezemeye sahiptir. Aşağıya doğru hafifçe genişleyen plaka biçimindeki göv-

30 Ayakucu taş: $115 \times 34-37 \times 11 \mathrm{~cm}$.

31 Lahit biçimi mezar ölçüleri: 70x193x75 cm.

32 Başucu taş1: $185 \times 29-38 \times 12 \mathrm{~cm}$.

33 Ayakucu taş1: 170x33-39x11 cm. 
de, bitkisel tepelikle taçlanmıştır. Üst üste akant yapraklarının kademeli olarak sıralanmasıyla oluşturulan kemer formunun yüzeyine üç iri gül motifi ve iki hatmi çiçeği kabartılmıştır. Silindirik görünümlü iki kademeli boyun formu ince düz silmeyle birbirine bağlanmıştır. Taşın gövde kenarları, yüzeyden yüksekçe kabartılmış dilimli akant yaprakları arasına serpiştirilmiş ikişerli ve üçerli gül motifinden oluşan bezeme ile sınırlandırılmıştır. Gövdenin eksenine ucu çatallı bir daldan gelişen fiyonk motifiyle bağlanmış asma dalı yerleştirilmiştir. Stilize edilerek işlenen asma dalı yayvan yaprakları, iki üzüm salkımı ve filizleri ile taş yüzeyine kabartılmıştır.

Taş No.13: Dikdörtgen prizması görünümünde kapak taşlı lahit mezar, ${ }^{34}$ başucu ve ayakucu taşından oluşmaktadır (F.14a). Lahitin alt kısmı kesme taş, üç kademe ile profillendirilmiş kapak taşı ise mermer malzeme ile yapılmıştır. Dikdörtgen levha biçimindeki kapak taşı üzerindeki oval açıklık çiçeklik kısmı olarak değerlendirilmiştir. Lahit yüzeyi bezemesizdir.

Mermer başucu taşının, aşağı doğru hafifçe genişleyen armudi formda plaka biçimindeki gövdesi ${ }^{35}$ bitkisel tepelikle taçlandırılmıştır. Tepelik yüzeyi ikişerli yaprak düzenlemeleriyle istiflenerek, katmerli beş gül motifiyle buket biçimi görünümünde taş yüzeyine kabartılmıştır. Gövde kenarları uçları içe ve dışa dönük dilimli akant yaprağı arasına üçerli gül motiflerinden oluşan dekoratif bir bordürle kuşatılmıştır. Aşağı doğru genişleye gövdesi uçları volütlü profillerle istiridye kabuğu biçiminde akant yaprağıyla birleşerek nihayetlenmiştir. Taş uçları dışa dönük yapraklarla sınırlanan bir levha ile lahitin üzerine yerleştirilmiştir (F.14b). Kitabe metni yatay şeritlerle oluşturulan panolar içine dokuz satır hâlinde celi sülüs hatla kabartılmıştır.

Kitabe metninin Latin harfleriyle yazılışı şu şekildedir:

Hüve'l-Hayyu'l-Bâki

Trabzon tüccârindan

Nemli-zâde merhum

El-Hâc Mahmûd Efendi'nin

Halîlesi Han Ăgası

Tâhir zâde Ăga'nnn kerimesi

Hanımcık Fâtıma Hanım' 'n ruhiçün

Fâtiha

Sene 1311 Fi 10 Recep (M. 17 Ocak 1894)

34 Lahit biçimi mezar ölçüleri: $75 \times 210 \times 80 \mathrm{~cm}$.

35 Başucu taşı: $180 \times 40-46 \times 12 \mathrm{~cm}$. 
Aynı malzeme ile yapılan ayakucu taşı ${ }^{36}$ form ve süsleme açısından başucu taşıyla aynıdır. Aşağı doğru hafifçe genişleyen plaka biçimindeki gövde bitkisel bir tepelikle taçlandırılmıştır. Akant yaprakları arasında beş gül motifinin oluşan tepelik iki kademeli bir boyunla daralarak gövde kısmına bağlanır. Eksene üç daldan gelişerek, taş gövdesini tamamen kaplayacak biçimde kıvrım dallar yerleştirilmiştir. Dallar arasına asimetrik biçimde laleler, üzüm salkımları, filizleri ve yapraklarıyla yüzeyden hafif kabartılarak işlenmiştir. Taşın alt kısmı başucu taşında olduğu gibi, volütlü dalların ortada yedi dilimli istiridye kabuğu motifiyle birleştirilmesiyle sonlandırılmıştır.

Taş No.14: Lahit görünümlü mezar ${ }^{37}$ dikdörtgen prizma formundadır. Başucu ve ayakucu taşından oluşur (F.15a). Lahitin alt kısmı kesme taş, kapak kısmı mermer malzeme ile yapılmıştır. Dikdörtgen levha biçiminde yerleştirilen kapak kısmının ortasında oval bir açıklık bulunmaktadır.

Mermer başucu taşının aşağı doğru hafifçe genişleyen armudi formda plaka biçimindeki gövdesi ${ }^{38}$ boyun formu ile daraltılarak bitkisel bir tepelikle taçlandırılmıştır. Buket biçiminde düzenlenen tepelik kısmına ince uzun şerit yaprakların arasında ortadaki daha büyük olmak üzere üç gül motifi kabartılmıştır. Dilimli akant yaprakları üç kademeli silmelerle bağlanarak boyun formu kazandırılmıştır. Gövde kenarları ise alttan ve üstten kontrast oluşturan düz-ters ' $C$ ' kıvrımlı katmerli akant yaprakların arasına yerleştirilen ikişerli gül motifiyle kuşatılmıştır (F.15b). Kitabe metni yatay şeritlerle oluşturulan kademeli sıralanan panolar içine yedi satır hâlinde celi sülüs hatla grift biçimde kabartılmıştır.

Kitabe metninin Latin harfleriyle yazılışı şu şekildedir:

Âh Mine'l-Mevt

Trabzonî Nemli-zâde

Merhûm El-Hâc Sâlih

A ̆̆a'nın halîlesi

Merhûme ve mă̆fûre

\section{Lehâ Fâtıma Hanım'ın}

Ruhiçün Fâtiha Sene 131328 Cemâziye'l-âhir (M.16 Aralık 1895)

Aynı malzeme ile yapılan ayakucu taş1 ${ }^{39}$ form ve bezeme açısından başucu taşıyla paralellik göstermektedir. Aşağı doğru hafifçe genişleyen armudi formdaki plaka biçimli gövde bitkisel bir tepelikle taçlandırılmıştır. Şerit

\footnotetext{
36 Ayakucu taşı: 180x39-46x13 cm.

37 Lahit biçimi mezar ölçüleri: $47 \times 183 \times 70 \mathrm{~cm}$.

38 Başucu taş1: 150x35-39x7 cm.

39 Ayakucu taş1: $133 \times 28-31 \times 7 \mathrm{~cm}$.
} 
ince uzun yapraklar arasına yerleştirilen üç gül motifi yüzeye dekoratif ve hacimli bir biçimde kabartılmıştır. Dilimli akant yapraklarının kenarları ' $\mathrm{C}$ ' kıvrımlarıyla sınırlanarak ortada ince düz bir silme ile bağlanarak boyun formu oluşturulmuştur. Gövde eksenine ayaklı, yayvan gövdeli, geniş ağızlı bir vazo yerleştirilmiştir. Vazo rokoko tarzı ' $S$ ' biçimi kulplara sahiptir. Vazo içinden 'S' kıvrımlı dallar üzerinde gül motifleri stilize edilerek lale ve yapraklar natüralist bir anlayışla gövdenin yüzeyini kaplayacak biçimde taş yüzeyine işlenmiştir.

\section{Karşıllaştırma ve Değerlendirme}

Çalışmada Trabzon ili, Tavanlı Cami Haziresi'nde yer alan 19. yüzyıla tarihlenen 14 kadın mezarı incelenmiştir. Mezarlar, şahideli toprak mezarlar ${ }^{40}$ ve lahit biçimli şahideli mezarlar ${ }^{41}$ olmak üzere iki grupta ele alınmışıtı ${ }^{42} .14$ mezardan 10'u şahideli toprak mezar (Ş.T.M No: 1-10), 4'ü ise şahideli lahit biçimi mezar grubundadır. (Ş.L.B.M No: 11-14). Toprak mezarlardan 6'sı başucu ve ayakucu taşına sahipken (Taş no: 1-5, 7) 4'ü (Taş no: 6, 8-10) sadece başucu taşına sahiptir. 4 adet lahit biçimi mezarın tamamında başucu ve ayakucu taşı (Taş no: 11-14) bulunmaktadır.

Şahideli toprak mezarların tarih sinırları H.1217/M.1802 ile H.1311/M.1893, lahit biçimi şahideli mezarların tarih sınırları ise H.1303/1885 ile H.1313/M.1894 yılları arasındadır.

10 adet toprak mezar tipinde baş ve ayakucu taşlarının tamamı mermer malzeme ile yapılmıştır. 4 adet lahit biçimi mezarın prizmatik gövdelerinde taş, baş ve ayakucu taşlarında ise yine mermer malzeme kullanılmıştır. Mezar taşlarında oyma ve kazıma tekniği uygulanarak kitabe metni, bezeme alçak ve yüksek kabartma olarak işlenmiştir.

İncelenen mezar taşlarının tamamında gövde biçimi plaka görünümlüdür. Bunların 7'si (Taş no: 1, 2, 4, 7-10) yukarıya doğru hafifçe genişleyerek yükselen, 3'ü (Taş no: 3, 5-6) birbirine paralel kenarlarla uzanan, lahit biçimi mezarların tamamı ise (Taş no: 11-14) aşağı doğru genişleyerek tekrar daralan armudi formda plaka görünümlü gövde biçimine sahiptir (Tablo 1).

Plaka şeklinde gövdeye sahip başucu taşlarının bir kısmı boyun formu ile daralarak farklı türlerde başlıklarla ${ }^{43}$, bir kısmı da boyun kısmı ile daralmaksızın sivri kemer, dilimli kemer, yarım daire biçimi kemer, üçgen benzeri veya

40 Toprak üstünde sadece baş ve ayakucu taşından oluşan mezar tipidir.

41 Prizmatik gövde, dışa taşıntılı kapak levhası, başucu ve ayakucu taşından oluşan mezar tipidir.

42 Şahideli toprak mezarlar Ş.T.M 1, 2... ve Ş.L.B.M. 11, 12 ... kısaltmasıyla verilmiştir.

43 Başlıklar her millete ve zamana göre değişen erkek ve kadınların başlarını örtmek üzere kullandıkları giyeceklerdir. Bunlara Farsça "başını örten" anlamına gelen "serpuş" da denilmektedir. (bk. Celal Esad Arseven, "Baş Giyimi, Baş Giyeceği”, Sanat Ansiklopedisi, C: I, 1983, s.182-185.) 
bitkisel bir tepeliklerle taçlandırılmıştır. Bu formlarda tepelikle taçlanan 11 kadın baş taşı bulunmaktadır.

Gövde kısmı yukarı doğru genişleyen 7 adet mezar taşından 3'ü üçgen tepelik (Taş no: 1, 2, 4); 3'ü bitkisel tepelik (Taş no: 7-9); biri ise rozet motifiyle (Taş no: 10) taçlandırılmıştır. Üçgen benzeri tepeliğe sahip 3 şahideden birinin alınlığı bezemesiz (Taş no: 4), ikisinin ise alınlığı bezemelidir (Taş no: 1, 2). Bir eserde (Taş no: 1) üçgen tepeliğin eksenine, ortası inci tanesi dolgulu, uçları volütlü ve C kıvrımlarıyla sınırlı, akant yaprakları ile süsleme yapılmıştır. Diğerinde ise (Taş no: 2) tepelik eksenine meyve tabağ 1 yerleştirilmiştir. İçinde üç üzüm salkımı bulunan kâsenin üst kısmı iri akant yapraklarıyla taçlandırılmıştır

Bitkisel motiflerden oluşan tepelik, 3 adet şahide de mevcuttur. Bunlardan birinde (Taş no: 7) bereket boynuzundan çıkan kenger ve akant yapraklarından oluşan bezeme görülür. Buket biçimi, bitkisel tepeliğe sahip diğer iki eserde ise (Taş no: 8,9 ) üst üste dizilmiş yapraklar arasına barok karakterli gül motifleri işlenmiştir. Bir eserde (Taş no: 9) Boyun kısmı oluşturacak biçimde yerleştirilen dallar enli bir kuşakla bağlanarak beşi bir yerde türü gerdanlıkla bezenmiştir. Diğerinde ise (Taş no: 8) iki kademeli dekoratif görünümlü bir boyun kısmı görülmektedir. Rozet biçimi tepelik bir eserde (Taş no: 10) ortası beş yapraklı çiçek motifiyle dolgulu on üç kollu yıldız motifi biçiminde kabartılarak "C" kıvrımlı iri birer yaprakla gövde kısmına birleştirilmiştir

Birbirine paralel kenarlarla uzanan plaka biçimindeki 3 mezar taşının tamamı (Taş no: 3, 5-6, ) silindirik formda kademeli bir boyunla daralarak, üzerinde tepelik ${ }^{44}$ bulunan fes/takke görünümlü başlıkla sonlandırılmıştır.

Aşağıya doğru genişleyerek daralan armudi formda plaka gövdeye sahip 4 adet mezar taşının tamamı (Taş no: 11-14) bitkisel tepelikle sonlandırılmıştır. Barok karakterli gül ve hatmi çiçeği motifleri, üst üste dizilmiş uçları aşağ doğru sarkan yapraklar arasına yüksek kabartma olarak pramidal bir düzende yerleştirilmiştir. Kademeli dekoratif görünümlü bir boyun kısmıyla gövde kısmına bağlanan bu grup, lahit biçimi mezarların şahidelerini oluşturmaktadır.

İncelenen başucu taşlarında kitabe metninin üstten kemer formu oluşturacak biçimde bir veya birkaç kademeli silme (Taş no: 3-4, 7-10), "C", "S" kıvrımlarından oluşan, barok- rokoko etkili bitkisel çerçeve (Taş no: 1-2) ya da bordürün uzantısıyla (Taş no: 8) sınırlandığı saptanmıştır. İki eserin kemer köşeliklerinde (Taş No: 1,8 ) barok karakterli stilize bitkisel motiflere yer veril-

44 Gümüş ve bakır malzemeden yapılan daire formlu basık koni görünümünde olan tepelikler, ya feslerin üst tablasını örtecek şekilde ya da doğrudan saç üzerine yerleştirilen etrafı altın, gümüş paralar ya da renkli taş boncuklarla süslenen başlık ya da başlık aksesuarı olarak adlandırılmaktadır. (bk. Reşad Ekrem Koçu, Türk Giyim Kuşam ve Süsleme Sözlüğü, Ankara, 1967, s. 227; Nevin Balta, Anadolu Kadın Başlıkları, Ankara 2014, s. 348, 375, 433; Fikri Salman, Türklerde Kıyafet Biçimleri, Başlangıcından Anadolu Selçuklularının Sonuna Kadar, Erzurum, 2013, s. 360361; M. Reşat Sümerkan, Trabzon Yöresi Geleneksel El Sanatları, Trabzon 1998, s. 140-141.). 
miştir. Kitabe yanları, genel olarak ince düz silmeler, süs sütunceleri ve bordür ile sınırlanır ve bazı eserlerde de çerçeve kullanılmaksızın düz bırakılmıştır.

Ayrıca lahit biçimi mezarların başucu taşlarının tamamında yine bitkisel karakterli girland motifiyle kitabe metninin üstten sınırlandırıldığı dört eser (Taşno: 11-14) bulunmaktadır.

Yapıldıkları dönemin, inançlarının, geleneklerinin, sanat anlayışının ortak ürünü olan mezar taşları ayrıca bulunduğu coğrafya itibarıyla Türk şehirlerinin tapu senedi vazifesini gören tarihî birer belge niteliğindedir (Eyice 1996: 124). Hayat ile ölüm, giden ile kalan arasındaki son diyaloğu içeren kitabe metinlerinde, Allah'ın isim ve sıfatlarından oluşan başlangıç ifadesi, Allah'tan istek, insanlara nasihat; sülale isimleri, ölüm yaş1, hastalıklar, isimler gibi biyografik ve sosyal durum belirten ifadeler ve dua sözleriyle başlayan Fatiha isteği, ölen kişinin ya da yakınlarının dilinden manzume olarak şiirsel bir anlatımla dile getirilmiştir. ${ }^{45}$ Genel olarak kitabe metninin sonunda tarihe yer verilmiştir (Tablo 2: Kitabe Bilgileri).

Tavanlı Cami Haziresinde gerek toprak mezarlar, gerekse lahit biçimi mezarların başucu taşlarının tamamında gövde yüzeyinde kitabe metni yer almaktadır. Başucu taşlarının 10 tanesinde kitabe metninde celi sülüs hat (Taş no: 1-6, 11-14) 4 tanesinde kitabe metninde celi talik hat (Taş no: 7-10) görülmektedir. Kitabe satırları, kabartma harflerle birbirine paralel doğrultuda veya sağa eğimli olarak düzenlenmiştir. Kitabe satırları 10 adet başucu taşında birbirine paralel satırlar hâlinde (Taş no: 1-4, 6-7, 11-14) 4 adet başucu taşında ise (Taş no: 5, 8-10) profillerle birbirinden ayrılarak, sağa eğimli olarak düzenlenmiştir.

Kitabe Metinlerinde Yer Alan Bilgiler: Kitabe metinlerinin başlangıç satırlarında, Allah'ın isim ve sıfatları ile insanın ölüm karşısındaki acizliğini içeren ifadeler kullanılmıştır.

Hüve'l-Bâki: “O (Allah) sonsuzdur.” (Taş no: 2, 6, 9, 11), Hüve'l-Hallâk'ul Bâki: "O (Allah) yaratıcı ve sonsuzdur". (Taş no: 1, 5), Hüve'l-Hayyu'l-Bâki: "O (Allah) diri ve sonsuzdur." (Taş no: 7, 13). Ah mine'l-mevt: "Ölümden ah" (Taş no: 8, 12, 14), Ah mine'l-mevt Hüve'l-Hallâk'ul-Baki: “Ölümden ah O (Allah) yaratıcı ve sonsuzdur." (Taş no: 10) vb. ifadelere Şefâ'ati li'ehlil-kebâiri min ümmetî (Taşno: 3), Yâ İlahi ol mübârek ism-i pâkin izzeti (Taş no: 4) gibi ayet ya da hadislere de rastlanmıştır.

Ölümün ardından, dünyanın geçici ve boş oluşu, yaşamın iyi değerlendirilmesi hususundaki düşünceler dile getirilmiştir. Ayrıca ölüm karşısında duyulan hüzün, esef gibi karışık duygu hâllerini içeren ifadeler de kitabelerde

45 Ayrıntılı bilgi için bk. Namık Açıkgöz, "Mezar Taşı Metinlerinde Ölüm”, Defin, İstanbul 2012, s. 265, 282-283; Şeref Boyraz, Türkiye'de Mezar Taşı Sözleri, Ankara, 2003, s. 79-91; Murat Çerkez, "Yozgat Gevheri Ali Efendi Camisi Haziresi Mezar Taşları”, Milli Folklor, 2013, Y11 25, S: 97, s. 179. 
yer almaktadır. Bu ifadeler ya ölen kişinin ağzından çıkmış gibi ya da bu kişinin yakınlarının dilinden mezar taşı metinlerine aktarılmıştır:

"Yürü ey bî-vefâ dünyâ seninle el-vedâ olsun işi cevr cefâ dünyâ seninle el-vedâ olsun fenâdan elçeküb Yâ Rab bakâya eyledim rthlet"; " İşi cevr cefâ dünyâ seninle el-vedâ olsun"; "Hâmûş olub şu kabrin içinde yatan dahi Söyler güler gezerdi senin gibi bir zaman"; "Mürg-ı dil uçdu kafesten cân pâresi kondu cennet bağına dilde kaldl yâresi hey meded bulunmadı vebâ emrâzlnın çâresi Genç yaşında meğer tekmil imiş va'desi”; "Gençliğinde fevt olup hubb-ı kavileri nemsubatini Firkatleriyle ne âl-ü gamdan ila yevmi'd-dâr Sinin-i hayfa kim yirmi üç iken yek ecel"; Ölen kişinin günahlarinın affedilmesi, yerinin cennet olması temennileri "Eyle kabrin ravza-i cennet ya İlâh'el âlemin Gece gündüz eylesünler huriler hizmeti"; "Kerem kil cürmümü afv et adn bana makâm olsun İlâhi ben günâhkârı haşırda eyleme rüsvây dilerim cürm ü isyânım senin afvinla mahv olsun" ifadeleriyle; Insanlardan beklenen kabir ziyareti ve dua isteği "Beni kul mağfiret ey Rabb-i Yezdân Bi-hakkı arş-l a'zam nûr-ı Kur'ân Gelüp kabrim ziyaret eyleyen ihvân"; "Gelüp kabrin ziyaret eyleyen ihvan-ı din Eylesünler ruhu pakin it rahmetle yâd"; "Gel şu mevtâ kabrine oku bir Fâtiha sûresi"

Tarih ibaresinin yer aldığı son satırdan önce yer alan ölünün ruhuna Fatiha suresinin okunması isteği 13 başucu taşında görülürken, birinde (Taş no: 9) aşırı tahribattan dolayı okunamamıştır. 2 eserde (Taş no: Taş no: 8,14 ) ise tarihle beraber son satırda verilmiş̧ir. Ölüler için ısrarla Fatiha sûresinin istenmesinin sebebi, Fatiha sûresinin Kur'ân'ın özünü ihtiva etmesi olarak açıklanmaktadır, ayrıca ölen kişinin Allah'ın bağışlayıcılığı ve merhametine sığınacağına inanılmaktadır (Laqueur 1997: 92-94; Boyraz 2003: 54, 120; Açıkgöz 2012: 282-283). Lahit biçimi mezarlarda, baş ve ayakucu taşları dünyanın geçiciliğini hatırlatırcasına gelip geçenlerin görüp Fatiha okuyacağı biçimde konumlandırılarak yola bakacak biçimde yerleştirilmiştir (Taş no: 11-14).

Mezar taşlarının tamamında ölüm tarihi belirtilmiştir. Bunlardan dokuzu yıl (Taş no: 1-5, 7-10), biri (Taş no: 12) ay ve yı1, dördü ise (Taş no: 6, 11, $13,14)$ gün, ay, y1l olarak hicri takvime göre verilmiştir. Tarih, genellikle son satırda işlenmiştir. Sadece bir eserde (Taş no: 7) Fatiha isteğinden önce verilmiştir.

Biyografik ve Sosyal Durum Belirten İfadeler: Tespit edilen Fatıma, Faika, Gül, Hafize, Habibe, Rakuş, Rukiyye, Saliha başucu taşlarında geçen isimlerdir. Fatıma dört eserde, diğerleri birer eserde karşımıza çıkmaktadır. Kitabe metinlerinde Nemlizâde (Taş no: 1, 10-14), Ahmet Çavuşzâde (Taş no: 2), Şatırzâde (Taş no: 3, 8), Temellizâde (Taş no: 6) gibi sülale isimleri tespit edilmiştir. 
Kadın mezar taşlarında eş, baba veya erkek kardeşin kimlik bilgileri (Eldem 2005: 138, 142) ile birlikte "kerimesi, ehli, helâli, refikası, zevcesi, validesi, kayın validesi, menkuhası" gibi tanıtıcı isimlerden sonra merhumenin ismi, "hatun" ve "hanım" ibareleri eklenerek ifade edilmiştir.

Yine kadın mezar taşları kitabe bilgilerinde ayırt edici unsur olarak isimlerden önce Allah'ın rahmetine kavuşmuş, esirgenmiş, bağışlanmış anlamlarında "merhume, merhûme ve mağfûre, merhûme ve mağfûre lehâ, merhûme ve mağfûre el muhtaç" gibi ifadelerden sonra Fatiha isteğine yer verilmiştir.

Kitabe metinlerinde ölüm yaşı bir eserde 23 (Taş no: 9) olarak geçerken, 3 eserde (Taş no: $3,7,8$ ) ise genç yaşta ölüm "gençliğimde başıma geldi ölüm iksiri", "ecel irdi bu gençlikte", "muradım alamadım" gibi cümlelerle ifade edilmiştir. Ölüm sebebi olarak kitabe metinlerinde bir eserde veba (Taş no: 3 ) bir eserde ise doğum yaparken (Taş No: 7) ifadeleri geçmektedir. Manzume olarak mezar taşı kitabelerini yazan şairlerin, "Zühdi" ve "Agâh" olarak mahlaslarının geçtiği iki eser tespit edilmiştir (Taş no: 7-8).

İncelenen 14 mezardan 10 tanesi ayakucu taşına sahiptir. Ayakucu taşlarında da gövde plaka görünümlü olup çeşitli tepeliklerle taçlandırılmıştır. Yukarıya doğru hafifçe genişleyerek yükselen plaka gövdeli ayakucu taşlarından 2'si (Taş no: 1, 7) üçgen tepelikle, diğer 2'si ise (Taş no: 4-5) sivri kemer formunda tepelikle sonlandırılmıştır. Paralel kenarlarla uzanan plaka biçimindeki 3 ayakucu taşından biri (Taş no: 2) üç dilimli kemer formuyla diğeri ise (Taş no: 3) soğan görünümlü başlıkla taçlandırılmıştır. Armudi formda plaka gövdeye sahip 4 adet ayakucu taşının tamamı (Taş no: 11-14) başucu taşlarında olduğu gibi bitkisel tepelikle sonlandırılmıştır. Gül demetleri, stilize ya da akant yaprakları arasına serpiştirilmiş görünümde tepelik yüzeyine kabartılmıştır. Ayakucu taşlarının tamamında yazıya yer verilmemiştir.

Üçgen tepelikle taçlanan ayakucu taşlarında, gövde kısmı bir eserde (Taş no: 1) hurma ağac1; diğer bir eserde (Taş no: 7) tepelik eksenine yerleştirilen, stilize palmet motifi, "C ve S" kıvrımlarının oluşturduğu yaprak motifleriyle sınırlanarak dendan motiflerinden oluşan bir bordürle tepelik ve bezemesiz gövde yüzeyi arasında geçiş sağlanmıştır. Sivri kemer formu ile taçlanan bir adet ayakucu taşının gövdesinde (Taş no: 4) uçları spiral döngülü ' $S$ ' biçimli kıvrım dallar taşın tüm yüzeyini kaplamaktadır. Üçgen tepelik ve soğan başlıkla sonlanan diğer iki ayakucu taşında (Taş no: 3,5 ) gövde yüzeyine servi ağacı motifi yerleştirilmiştir. Bunlardan birinde (Taş No: 3) servi ağacına sarılı dallar arasında üzüm salkımları, diğerinde ise (Taş no: 5) 'C' kıvrımlı silmelerle oluşturulan dekoratif bir kemerle sınırlandırılan gövde yüzeyine servi ağacı motifi yalın bir biçimde yerleştirilmiştir. Dilimli kemer formunda tepeliğe sahip olan bir ayakucu taşında (Taş no: 2) gövde yüzeyinde bezemeye yer verilmemiştir. Lahit biçimi mezarlara ait bitkisel tepelikle taçlanan ayakucu 
taşlarından 3'ünde (Taş no: 11-13) asma dalı yaprakları, üzüm salkımlarından oluşan bezeme, 1 tanesinde ise (Taş no: 14) vazo içinden ' $S$ ' kıvrımlı dallar üzerinde gül ve lale çiçeklerinden oluşan kompozisyon natüralist bir anlayışla gövdenin yüzeyine işlenmiştir.

Trabzon Tavanlı Cami Haziresinde incelediğimiz 19. yüzyıl ait kadın mezar mezarlarının gerek başucu gerekse ayakucu taşlarında görülen motifler çok geniş bir repertuara sahiptir. Bitkisel ve geometrik bezemenin ağırlıkta olduğu süsleme programında yer yer vazo, kâse, fiyonk gerdanlık gibi nesnelerinde kullanıldığı görülmektedir. Tavanlı Cami Haziresi’nde bulunan 19. yüzyıla ait şahideler malzeme, işleniş niteliği, form ve bezeme anlayışı bakımından aynı yüzyıl Anadolu ve Balkanlar'daki pek çok mezar taşı ile ortak özellikler göstermektedir.

Üçgen tepelikle sonlanan plaka biçiminde gövdeye sahip şahideler, genellikle dilimli akant yaprakları ya da ayaklı, yivli gövdeli geniş ağızlı bir meyve tabağ 1 içinde yapraklarıyla birlikte meyve tasvirleriyle bezenmiştir (Taş no: 1, 2, 4). Bu gruba giren benzer şahideler ${ }^{46}$ Trabzon Sülüklü Şehir Mezarlı̆̆ı, Samsun Kökçüoğlu Mezarlığı, Rumelihisarı Şehitlik Dergâhı Haziresi, Amasya Mehmet Paşa Camisi Haziresi, Göynük Gazi Süleyman Paşa Cami Haziresi, Akhisar Ulu Cami ve Paşa Cami Hazirelerinde yer almaktadır.

Barok karakterli yapraklar arasında iri çiçek demetleri, vazo içinde çiçekler akant yaprakları arasında kâse içinde meyve tasvirleri ya da yaprak demetlerinden oluşan bitkisel tepelikli plaka biçimindeki şahidelere Anadolu'da Trabzon Sülüklü Şehir Mezarlığı, Samsun Kökçüoğlu ve Tekeköy Mezarlı̆̆g, Kastamonu Şeyh Şaban-1 Veli Camisi ve Türbesi Haziresi, Kastamonu Gazi Cami ve Türbesi Haziresi, Akçabaat Serdarzâdeler aile mezarlığında, Amasya Yukarı Türbe Bahçesi ve Şirvanlı Cami Haziresi, Balıkesir Şeyh Lütfullah Cami Haziresi, Safranbolu Yörük Köyü Mezarlığında, Yalova'nın Altınova ilçesi Fevziye Köyü Cami Haziresi, İzmit Maşûkiye Merkez Cami Haziresi, Rumelihisarı Şehitlik Dergâhı Haziresi, Eyüp Sultan ve çevresinde bazı hazirelerde rastlanmaktadır. ${ }^{47}$

46 Krș. Kader Yer, “Trabzon Sülüklü Şehir Mezarllğı’ndaki 18. Yüzyll Mezar Taşlarl”, Yayımlanmamıș yüksek lisans tezi, Ankara, Gazi üniversitesi, 2004. Fotoğraf: 9, 16, 18, 20, 22, 30, 34, 41, 42, 66, 68, 71, 95, 104, 116, 136, 170; Hülya Ölçay, Trabzon Sülüklü Şehir Mezarlı̆̆ 19. Yüzyıl Kadın Mezar Taşları, Yayımlanmamıș yüksek lisans tezi, Ankara, Gazi üniversitesi, 2004 Fotoğraf: 16, 18, 19, 28, 63, 92, 132, 158; Eyüp Nefes, Samsun Yöresinde Bulunan Mezar Taşları. Yayımlanmamış doktora tezi. Samsun, OMÜ, 2002. Fotoğraf: 21, 35; Günnur Aydoğdu, Amasya Mezar Taşları. Yayımlanmamış Yüksek Lisans Tezi. Ankara, Gazi Üniversitesi, 1997. Fotoğraf: 102; Halit Çal, "Göynük (Bolu) Şehri Türk Mezar Taşları", Vakıflar Dergisi, S. 30, Ankara 2007. Fotoğraf: 48, 69, 97, 99, 113; Tuba Erdem, Akhisar Ulu Cami ve Pazar Cami Hazirelerindeki Mezar Taşları. Yayımlanmamış yükssek lisans tezi, Ankara, Gazi üniversitesi, 2009. Fotoğraf: 14, 15, 19, 20, 21, 22, 24, 25, 36, 39, 41, 54; Günay Kut- Edhem Eldem, Rumelihisarı Şehitlik Dergahı Mezar Taşları, İstanbul, 2010, s. 198, 211, 315; Süleyman Berk, Zeytinburnu'nun Tarihi Mezar Taşları, Zamanı Aşan Taşlar, İstanbul, 2015. Mezar Taşı No: 636, 644 (Merkez Efendi Mezarlığı); Halit Çal-Gazanfer İltar Giresun İli Osmanlı Mezar Taşları, Ankara, 2011. Mezar taşı no: 103, 107, 109, 110, 116 (Espiye Frengi Mezarlığı).

47 Krş. Hülya Ölçay, agt., fotoğraf: 8, 26, 45, 51, 69, 78, 85, 88, 148, 162, 167; Eyüp Nefes, a.g.t., Fotoğraf: 74, 88, 92, 129, 137, 159; Meral Taşdemir, Kastamonu Şeyh Şaban-ı Veli Camisi ve Türbesi Haziresi'nde Yer Alan Mezar Taşları. 
Çok kollu iri rozetle Taçlanan ve gövde kısmına S kıvrımlara sahip yapraklarla birleştirilen plaka biçiminde şahidelerle ortak özellik taşıyan eserlere Anadolu ve Balkanlar'da, Trabzon Sülüklü Şehir Mezarlığı'nda, Samsun Kökçüoğlu Mezarlığı, Şeyh Şaban-1 Veli Camisi ve Türbesi Haziresi, Kastamonu Gazi Cami ve Türbesi Haziresi, Göynük Gazi Süleyman Paşa Cami Haziresi, Balıkesir Şeyh Lütfullah Cami Haziresi, Üsküp Alaca Cami Haziresi ve Üsküp İsa Bey Cami Haziresi, Rumelihisarı Şehitlik Dergâhı, Safranbolu Yörük Köyü Mezarlı̆̆ı'nda rastlanılmaktadır ${ }^{48}$.

Fes/takke biçimi başlık üzerinde tepelikli eserler (Taş no: 11-14) aşağ1 doğru genişleyen bir boyunla plaka biçimindeki gövdeye bağlanan şahidelerin Anadolu'da benzer örnekleri, ${ }^{49}$ Trabzon Sülüklü Şehir Mezarlığı, Trabzon Akçaabat Mezarlık Cami yanındaki Serdar zadelere ait aile Mezarlığı, Samsun Kökçüoğlu Mezarlığı, Kastamonu Gazi Cami ve Türbesi Şeyh Şaban-1 Veli Camisi ve Türbesi Haziresi, Amasya Saraçhane Cami Haziresi, Göynük Akşemseddin Türbesi Haziresi, Ayaş Sinanlı Köyü Mezarlığı, Rumelihisarı Şehitlik Dergâhı Haziresi, Yalova'nın Altınova ilçesi Hersekzâde Ahmet Paşa Cami Haziresinde görülmektedir.

Trabzon Gülbahar Hatun Camisi, Tavanlı Cami ve Küçük İmaret Mezarlığı'nda çeşitli formlarda tepelikle sonlanan plaka gövdeli 10 adet ayak taşı bulunmaktadir.

Yayımlanmamış yüksek lisans tezi, Ankara, Gazi üniversitesi, 2003, Fotoğraf: 40, 96, 102, 108; Günnur Aydoğdu, a.g.t., Fotoğraf: 124, 132; Murat Yüksel, Murat Yüksel, Akçaabat'ta Türk-İslam Eserleri ve Kitabeler, Akçaabat, 2006, s.90, 100, 111, 124; Halit Çal-Özlem Ataoğuz Çal, age., 2008a, s. 99, 109, 129; Gül Tunçel, "Ayaş Mezar Taşları”, Sanat Tarihi Dergisi, Yrd. Doç. Dr. Lâle Bulut’a Armağan, S.XIV/1, İzmir, 2005a, s. 277-307. Fotoğraf: 10; Gül Tunçel, agm., 2002. Fotoğraf: 4, 7; Murat Çerkez, agm., Fotoğraf: 3a, 3b, H. Kamil Biçici, "Safranbolu Yörük Köyü Mezarlı̆̆ında Bulunan Süslemeli Mezar Taşları”, Sosyal Bilimler Dergisi, S. 20, 2008, s. 322. Fotoğraf: 13; Lütfi Şeyban, "Yalova'nın Altınova İlçesindeki Osmanlı Mezartaşları ve Kitâbeleri", Akademik Incelemeler Dergisi C.5, S.2 2010, s.222 (Fevziye Köyü Camiai Hazîresi); Lütfi Şeyban- Ayşenur Altun...;” İzmit Maşûkiye Merkez Cami Hazîresi'nde Bulunan Osmanlı Mezar Taşları" Akademik Sosyal Araştırmalar Dergisi, Yıl: 2, S: 5, Eylül 2014. Mezar taşı no: 5-7, 20, 31-33; Günay Kut-Edhem Eldem, age. s.172, 218, 274; Süleyman Berk, age. Mezar taş1 no: 97, 100, 132, 239 (Merkez Efendi Mezarlı̆̆ı).

48 Krş. Hülya Ölçay, a.g.t., Fotoğraf: 31, 42, 40, 50, 52, 126, 151; Eyüp Nefes, a.g.t., Fotoğraf: 77, 83, 108; Meral Taşdemir, a.g.t., Fotoğraf: 34, 41, 110; Halit Çal-Özlem Ataoğuz Çal, age 2008a, s.118; Halit Çal, agm. 2007, Fotoğraf: 157, 161; Gül Tunçel, “Üsküp İsa Bey Cami...”, 2005b. Fotoğraf: 10; Gül Tuncel, "Üsküp Alaca Cami....", 2005c Fotoğraf: 14, 15, 16; Necmi Ülker,” Balıkesir-Şeyh Lütfullah Camisi Haziresi Mezar Kitabeleri (XVIII.-XX. Yüzyll)”, VIII. Araştırma Sonuçları Toplantısı (28 Mayıs-1 Haziran 1990), Ankara, 1991, Fotoğraf: 9; H. Kamil Biçici, agm. s. 322. Fotoğraf: 7; Lütfi Şeyban- Ayşenur Altun..., agm. 2014. Mezar taşı no: 1, 13, 35, 40; Günay KutEdhem Eldem, age. s. 227; Süleyman Berk, age. Mezar taşı no: 23, 80, 94, 146, 160 (Yenikapı Mevlevihanesi).

49 Krş. Hülya Ölçay, agt., Fotoğraf: 1, 2, 3, 6, 9, 17, 20, 21, 29, 67, 71, 75, 76, 80, 99, 106, 108, 111, 122, 140; Eyüp Nefes, agt., Fotoğraf: 40, 43; Meral Taşdemir, agt. Fotoğraf: 32; Günnur Aydoğdu, agt. Fotoğraf: 105, 107, 140; Halit Çal-Özlem Ataoğuz Çal, age. 2008a, s.87, 93; Halit Çal, agm. 2007. Fotoğraf: 79, 177; Lütfi Şeyban, agm. 2010, s.183, 189, 201, 217 (Hersekzâde Ahmet Paşa Camisi Hazîresi); Günay Kut-Edhem Eldem, age. s.266, 316; Süleyman Berk, age. Mezar taşı no: 18, 181, 196, 417 (Topkapı Çamlık Mezarlıkları). 
Gövde yüzeyinde genellikle hurma ağac1 ${ }^{50}$, asma dal ${ }^{51}$, servi ağac1 $1^{52}$ ve S kıvrımlı stilize çiçek ve yapraklardan oluşan bezeme unsurlar ${ }^{53}$ betimlenmiştir. Anadolu'da benzer örneklerine Trabzon Sülüklü Şehir Mezarlığı'nda, Şeyh Şaban-1 Veli Camisi ve Türbesi Haziresi, Gazi Cami ve Türbesi, Akhisar Ulu Cami ve Paşa Camisi Hazireleri, Edirne Sarıca Paşa Camisi Haziresi, Edirne Zehr-i Mar Camisi Haziresi, İstanbul Zal Mahmut Paşa Haziresi ile Eyüp Sultan Cami Haziresi, Edirnekapı Mezarlığı, Mihrişah Valide Sultan Türbesi Haziresi ve Safranbolu Yörük Köyü Mezarlığı'nda rastlanmaktadır.

\section{Sonuç}

Malzeme-teknik, form, başlık/tepelik, kitabe metinleri bakımından birer sanat eseri olan ve tarihî belge niteliği taşıyan Trabzon Tavanlı Cami Haziresi'nde 19. yüzyıla tarihlenen kadın mezar taşları döneminin karakteristik özelliklerini yansıtmaktadır.

Trabzon Tavanlı Cami Haziresi'nde 19. yüzyıla tarihlenen kadın mezarlarında on dört adet başucu on adet ayakucu taşı incelenmiş̧ir. Tamamında mermer malzeme kullanılan şahideler oyma tekniği ile alçak-yüksek kabartma olarak kitabe metni ve bezemeler oluşturulmuştur.

Trabzon Tavanlı Cami Haziresi kadın mezar taşlarında form bakımından çeşitlilik söz konusudur. Tamamı plaka gövdeli mezar taşlarında, aşağıdan yukarı doğru genişleyen, paralel kenarlarla uzanan ya da aşağı doğru genişleyerek tekrar daralan armudi gövde formu görülür. Plaka şeklinde gövdeye sahip başucu taşlarının bir kısmı boyun formu ile daralarak farklı türlerde başlıklarla, bir kısmı da boyun kısmı ile daralmaksızın sivri kemer, dilimli kemer, yarım daire biçimi kemer, üçgen benzeri veya bitkisel bir tepeliklerle taçlandırılmıştır.

Baş taşlarında görülen kitabe metni genel olarak kemer formu meydana getiren silme kuşağı ile üstten sınırlandırılarak kemer köşeliklerine barok karakterli motifler yerleştirilmiştir. Kitabe yanları ise silme, süs sütunceleri ya

50 Krş. Kader Yer, a.g.t., Fotoğraf: 38, 47, 105; Hülya Ölçay, a.g.t., Fotoğraf: 33, 53, 157; Eyüp Nefes, a.g.t., Fotoğraf: 44, 78, 104; Meral Taşdemir, a.g.t., Fotoğraf: 20, 24, 28, 36, 45, 52, 83, 92, 125; Günnur Aydoğdu, a.g.t., Fotoğraf: 110 , 114; Halit Çal-Özlem Ataoğuz Çal, age. 2008a s. 90; Halit Çal, agm. 2007 Fotoğraf: 2, 3, 6; Kamil Biçici, agm. agm. s.322. Fotoğraf: 2; Halit Çal-Gazanfer İltar, age.Mezar taşı no: 66 (Bulancak/ Burnucu Köyü Karaibrahimoğulları Mezarlığı), Mezar taşı no: 122 (Espiye/ Çavuşlu Beldesi Mezarlığı).

51 Krş. Kader Yer, a.g.t., Fotoğraf: 91 131; Hülya Ölçay, a.g.t., Fotoğraf: 90, 91, 150; Meral Taşdemir, a.g.t., Fotoğraf: Necmi Ülker, “Balıkesir Şeyh Lütfullah Camisi ...”, Fotoğraf; 8; H.Kamil Biçici, agm. s. 322. Fotoğraf: 4.

52 Krș. Kader Yer, a.g.t., Fotoğraf: 142; Meral Taşdemir, a.g.t., Fotoğraf: 18, 117, 103; Halit Çal-Özlem Ataoğuz Çal, age. 2008a s.93, 133; Tuba Erdem, a.g.t., Fotoğraf: 85, 89; Ayla Ersoy, "Eyüp’teki Mezar Taşlarında Selvi Ağacı Kültü” V. Eyüp Sultan Sempozyumu, Tebliğler (1-13 Mayıs 2001) İstanbul, 2002, s. 90-95, Fotoğraf: 1, 2, 5; Cebe Özer, " Edirne'de Osmanlı Dönemi Natürmort Süslemeli Mezar Taşları”, Yayımlanmamış Yüksek Lisans Tezi, Ankara, Gazi Üniversitesi, 1993. Fotoğraf: 46, 60; Halit Çal-Gazanfer İltar, age. Mezar taşı no: 188 (Piraziz/ Beyler Mezarlığ 1 ).

53 Krş. Eyüp Nefes, a.g.t. Fotoğraf: 23, 50, 82, 130; Meral Taşdemir, a.g.t., Fotoğraf: 64, 73, 56, 60, 63, 35, 49; Günnur Aydoğdu, a.g.t. Fotoğraf: 124, 133; H.Kamil Biçici, agm. s. 323. Fotoğraf: 24; Günay Kut-Edhem Eldem, age. s. 385386. 
da bordürler ile sınırlandırılmıştır. Kitabe satırları silmelerle oluşturulan panolar içine birbirine paralel ya da sağa eğimli satırlar şeklinde düzenlenmiştir. Kitabe metinlerinin başlangıç kısmında, ölen kişi hakkındaki düşünceler ile bu kişinin yakınlarının hissettikleri duygular ve Allah'tan istenen bazı dilekler de yer almaktadır. Metinlerde insanlara nasihat içeren sözler bulunmaktadır. Nasihat verilen bu insanlardan, ölen kişi için Fatiha duasının okunması isteği ile ilgili ifadelere de yer verilmiştir. Ayrıca ölen kişinin ismi, aile ya da baba adı, meslek ismi, ölüm yaşı ve ölüm sebebinin belirtildiği biyografik ve sosyal durum belirten ifadelerde mevcuttur.

Trabzon Tavanlı Cami Haziresi'nde yer alan 19. yüzyıla tarihlenen kadın mezar taşları mahallî üsluptan ziyade Osmanlı İmparatorluğu'nun farklı merkezlerindeki şahideler yanında diğer sanat eserlerindeki genel gelişim çizgisiyle benzerlikler göstermektedir. Ayrıca şahideler, form ve bezeme özellikleri bakımından başkent İstanbul ekolüne benzerliğiyle dikkat çekmektedir. 19. yüzyıl kadın mezar taşlarında özellikle tepelik ve başlıklarda gerek İstanbul'da gerek diğer Anadolu kentlerinde gerekse Balkanlar'da aynı tür formların kullanıldığı tespit edilmiştir. Bu durum, yüzyılın modasını ve gelişimini yansıtması bakımından büyük önem taşımaktadır. Trabzon'un eski çağlardan beri önemli bir liman kenti ve ticaret merkezi olması sebebiyle şahidelerin sipariş üzerine İstanbul'dan geldiği ya da Trabzon'daki atölyelerde İstanbul'dan gelen şablonlarla yapıldığını düşündürmektedir.

\section{Kaynakça}

AÇIKGÖZ, Namık (2012), "Mezar Taşı Metinlerinde Ölüm”, Defin, (Editör: Emine Gürsoy Naskali), İstanbul, 265-283.

ALYILMAZ, Cengiz (2012), "Eski Türklerde Mezar Geleneği”, Defin, (Editör Emine Gürsoy Naskali), İstanbul, 179-188.

ARSEVEN, C. Esad (1983), "Baş Giyimi, Baş Giyeceği”, Sanat Ansiklopedisi, C: I, İstanbul, 182-185.

AYDOĞDU, Günnur (1997), Amasya Mezar Taşları, Yayımlanmamış Yüksek Lisans Tezi Ankara, Gazi Üniversitesi.

BERK, Süleyman (2015), Zeytinburnu'nun Tarihi Mezar Taşları Zamanı Aşan Taşlar, İstanbul: Zeytinburnu Belediyesi Kültür Yayınları.

BİÇİCI, H. Kamil (2008), "Safranbolu Yörük Köyü Mezarlığında Bulunan Süslemeli Mezar Taşları", Sosyal Bilimler Dergisi, S: 20, 297- 324.

BOYRAZ, Şeref (2003), Türkiye'de Mezar Taşı Sözleri, Ankara: Akçağ Yayınları.

ÇAL, Halit-Gazanfer İltar (2011), Giresun İli Osmanlı Mezar Taşları, Ankara: Giresun Valiliği.

ÇAL, Halit (2007), “Göynük (Bolu) Şehri Türk Mezar Taşları”, Vakıflar Dergisi, S: XXX, Ankara, 295-379.

ÇAL, Halit-A. Özlem ÇAL (2008a), Kastamonu Atabey Gazi Camisi ve Türbesi Hazirelerindeki Mezar Taşları, Ankara: Kastamonu Belediyesi. 
ÇAL, Halit (2008b), “Ah Mine’l-Mevt/Kastamonu Şehrindeki 14.-20. Yüzyıl Mezar ve Mezar Taşları”, Üsküdar'a Kadar Kastamonu, İstanbul, 356-358.

ÇERKEZ, Murat (2013), "Yozgat Gevheri Ali Efendi Camisi Haziresi Mezar Taşları", Milli Folklor, S: 97, 178-194.

ÇORUHLU, Yaşar (1999), “Kurgan ve Çadır” Çadır (Yurt)'dan Kümbet ve Türbeye Geçiş”, Geçmişten Günümüze Mezarlık Kültürü ve İnsan Hayatına Etkileri Sempozyumu (1820 Aralık 1998), İstanbul, 49-50.

ELDEM, Edhem (2005), İstanbul'da Ölüm Osmanlı Íslam Kültüründe Ölüm ve Ritüelleri, İstanbul: Osmanlı Bankası Arşiv ve Araştırma Merkezi.

ERDEM, Tuba (2009), “Akhisar Ulu Cami ve Pazar Camisi Hazirelerindeki Mezar Taşları", Yayımlanmamış Yüksek Lisans Tezi, Ankara, Gazi Üniversitesi.

EYİCE, Semavi (1996), "Mezarlık ve Hazireler", İslam Dünyasında Mezarlıklar ve Defin Gelenekleri, C: I, Ankara, 123-134.

KAHRAMAN, Ömer (2003), Trabzon'da Türk Devri Mimar Eserleri, Yayımlanmamış Yüksek Lisans Tezi, Erzurum, Atatürk Üniversitesi.

KARAMAĞARALI, Beyhan (1999), "Kültür Tarihimiz Bakımından Mezar Taşlarının Önemi ve İkonografisi” Geçmişten Günümüze Mezarlı Kültürü ve İnsan Hayatına Etkileri Semроzуити (18-20 Aralık 1998), İstanbul, 33-46.

KARAMÜRSEL, Alım (2002), “Türkler'de Mezar Geleneği”, Türkler, C: III, (Editör: Salim Koca vd.), Ankara, 76-79.

KARPUZ, Haşim (1996), “Trabzon İl Merkezi ve İlçelerindeki Önemli Tarihi Yapılar”, Trabzon, Ankara, 103-133.

KOCASAVAŞ, Yıldız (2002), “Eski Türklerde Yas ve Ölü Gömme Adetleri”, Türkler, C: III, (Editör: Salim Koca vd.), Ankara, 67-75.

KOÇU, R. Ekrem (1967), Türk Giyim Kuşam ve Süsleme Sözlüğ̈̈, Ankara: Sümerbank Kültür Yayınları.

KUT, Günay-Edhem Eldem (2010), Rumelihisarı Şehitlik Dergahı Mezar Taşları, İstanbul: Boğaziçi Üniversitesi Yayınevi.

LAQUEUER, H. Peter (1997), Hüve'l-Baki, Ístanbul'da Osmanlı Mezarliklarl ve Mezar Taşları, İstanbul: Tarih Vakfi Yurt Yayınları.

NEFES, Eyüp (2002), Samsun Yöresinde Bulunan Mezar Taşları, Yayımlanmamış Doktora Tezi, Samsun, On Dokuz Mayıs Üniversitesi.

ÖLÇAY, Hülya (2004), Trabzon Sülüklü Şehir Mezarlı̆ğ 19. Yüzyıl Kadın Mezar Taşları, Yayımlanmamış Yüksek Lisans Tezi, Ankara, Gazi Üniversitesi.

ÖZER, Cebe (1993), Edirne'de Osmanlı Dönemi Natürmort Süslemeli Mezar Taşlarl, Yayımlanmamış Yüksek Lisans Tezi, Ankara, Gazi Üniversitesi.

SÖZEN, Metin- Uğur TANYELİ (1992), Sanat Kavram ve Terimleri Sözlüğ̈̈, İstanbul.

ŞEYBAN, Lütfi (2010, ) "Yalova'nın Altınova İlçesindeki Osmanlı Mezar Taşları ve Kitâbeleri”, Akademik Incelemeler Dergisi, C: 5, S: 2, 172-226.

ŞEYBAN, Lütfi-Ayşenur ALTUN (2014), "İzmit Maşûkiye Merkez Câmii Hazîresinde Bulunan Osmanlı Mezar Taşları”, Akademik Sosyal Araştırmalar Dergisi, S: 5, Eylül, 309-368.

TAŞDEMIR, Meral (2003), Kastamonu Şeyh Şaban-ı Veli Camisi ve Türbesi Haziresi'nde Yer Alan Mezar Taşları, Yayımlanmamış Yüksek Lisans Tezi, Ankara, Gazi Üniversitesi. 
TULUK, Ö. İskender- H. İbrahim DÜZENLİ (2010), "Yitik Mirasın İzinde: Trabzon'da Osmanlı Camisi ve Mescitleri (1461-1583)”, Trabzon Kent Mirası, İstanbul, 55-92.

TUNÇEL, Gül, "Türklerde Mezar Taşı Geleneğine Kısa Bir Bakış", Bilge (1996/8), Ankara, 1996, 16-18.

TUNÇEL, Gül (2002), “Beypazarı Müzesindeki Mezar Taşları”, Hacettepe Üniversitesi Edebiyat Fakültesi Sanat Tarihi Bölümü, Ortaçağ'da Anadolu, Prof. Dr. Aynur Durukan'a Armağan, Ankara, 441-456.

TUNÇEL, Gül (2005a), “Ayaş Mezar Taşları”, Sanat Tarihi Dergisi, Yrd. Doç. Dr. Lâle Bulut'a Armağan, S: XIV/1, İzmir, 277-307.

TUNÇEL, Gül (2005b), “Üsküp İsa Bey Cami Haziresi’ndeki Şahideler”, Erdem, C: 15, S: 3, Ankara, 59-85.

TUNÇEL, Gül (2005c), “Üsküp Alaca Cami Haziresi'ndeki Şahideler”, Hacettepe Üniversitesi Edebiyat Fakültesi Dergisi, C: 22, S: 1, Ankara, 215- 236.

ÜLKER, Necmi (1991), "Balıkesir-Şeyh Lütfullah Camisi Haziresi Mezar Kitabeleri (XVIII.-XX. Yüzyıl)", VIII. Araştırma Sonuçları Toplantısı (28 Mayıs-1 Haziran 1990), Ankara, 457-476.

YAZAR, Turgay (1999), "Çadır-Bark-Türbe”, Geçmişten Günümüze Mezarlık Kültürü ve Insan Hayatına Etkileri Sempozyumu (18-20 Aralık 1998), 418-431.

YER, Kader (2004), Trabzon Sülüklü Şehir Mezarlığı'ndaki 18. Yüzyıl Mezar Taşları, Yayımlanmamış Yüksek Lisans Tezi, Ankara Gazi Üniversitesi.

YÜKSEL, Murat (2006), Akçaabat'ta Türk-İslam Eserleri ve Kitabeler, Akçaabat.

YÜKSEL, Murat (2000), Trabzon'da Türk İslam Eserleri ve Kitabeleri, C: I-II, Trabzon: Trabzon Belediyesi Kültür Yayınları.

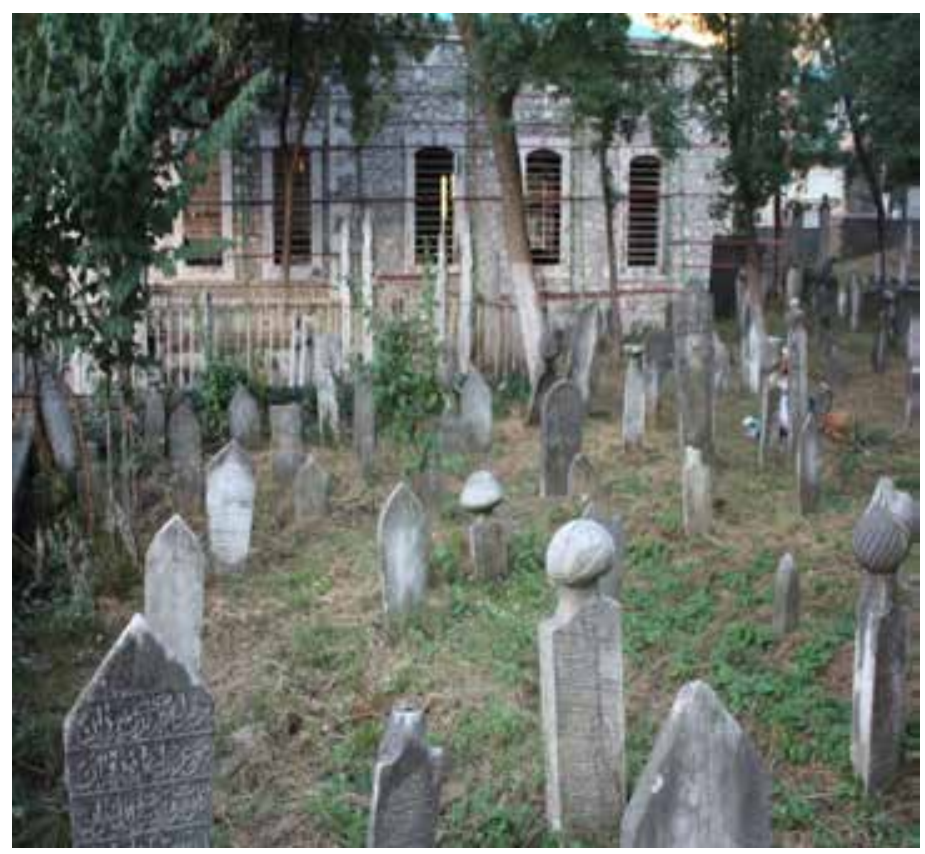




\section{F.1 Tavanlı Cami Haziresi Genel Görünümü}

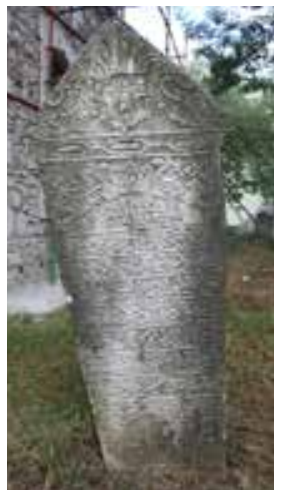

F. $2 \mathbf{a}$

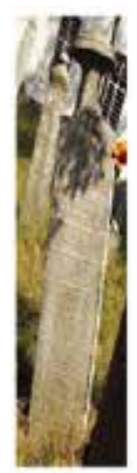

F. $4 \mathbf{a}$

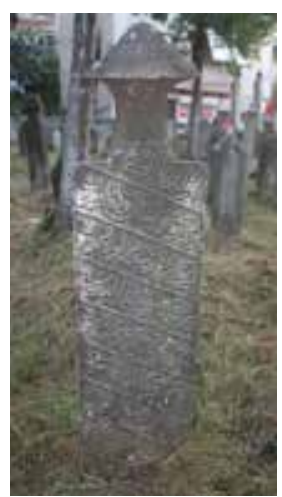

F. $6 \mathbf{a}$

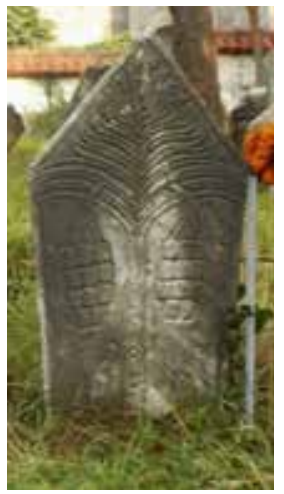

F. 2 b

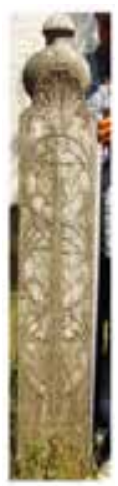

F. $4 b$

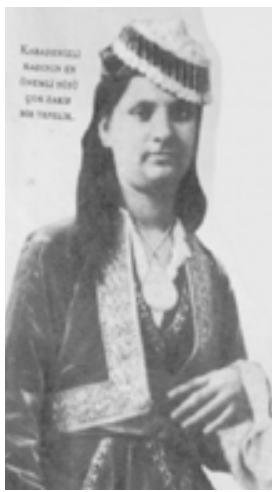

F. $6 \mathbf{b}$

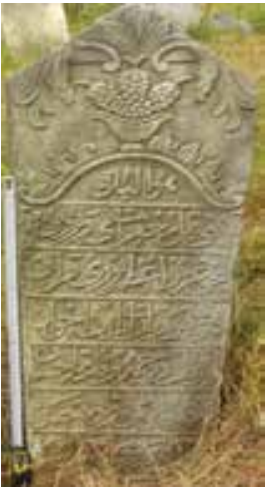

F. 3a

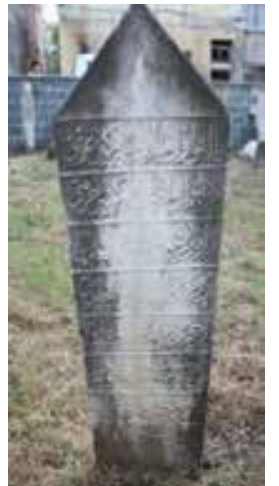

F. $5 \mathbf{a}$

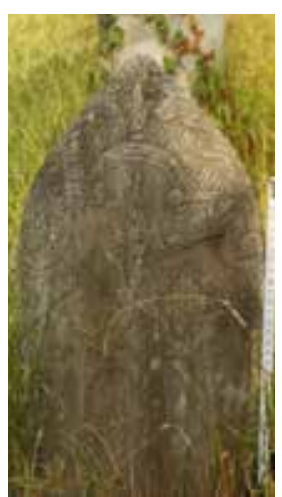

F. $6 c$

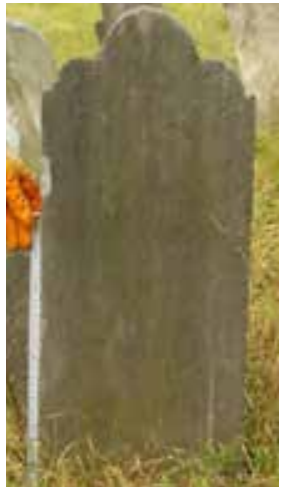

F. 3b

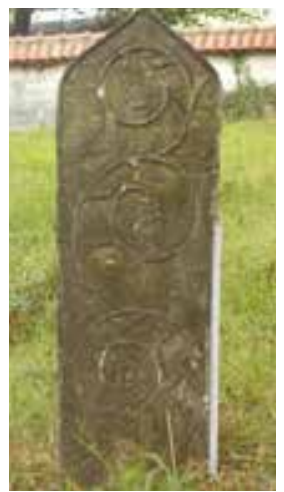

F. $5 b$

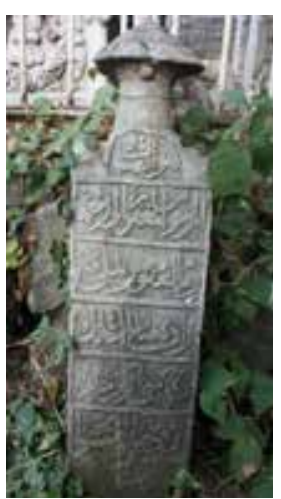

F. $7 \mathbf{a}$ 


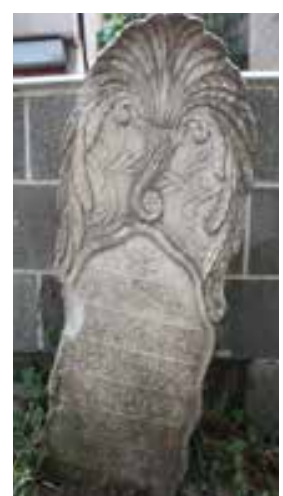

F. $8 \mathbf{a}$

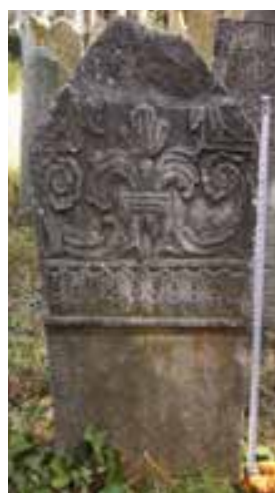

F. $8 b$

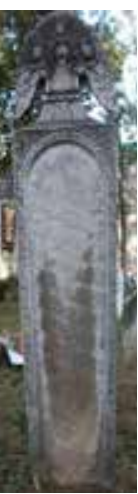

F. 9

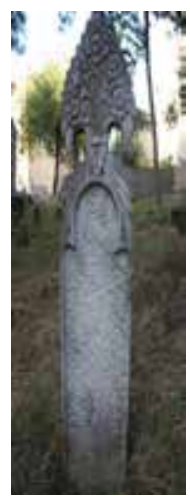

F. 10

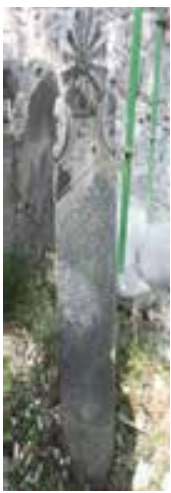

F. 11

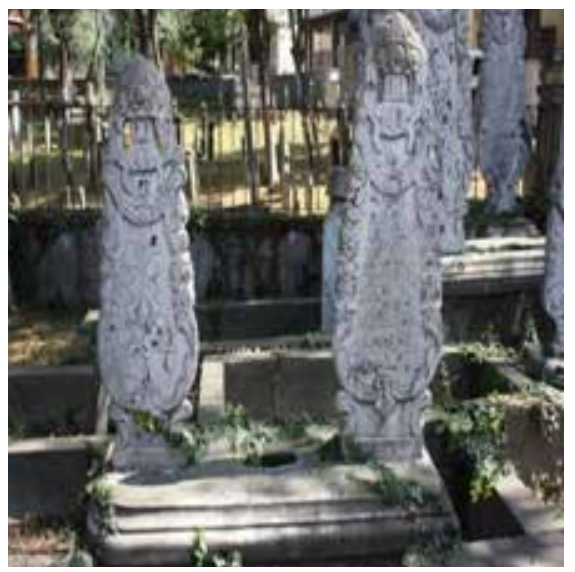

F. $12 \mathrm{a}$

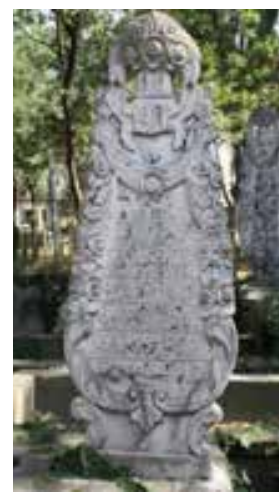

F. 12b 


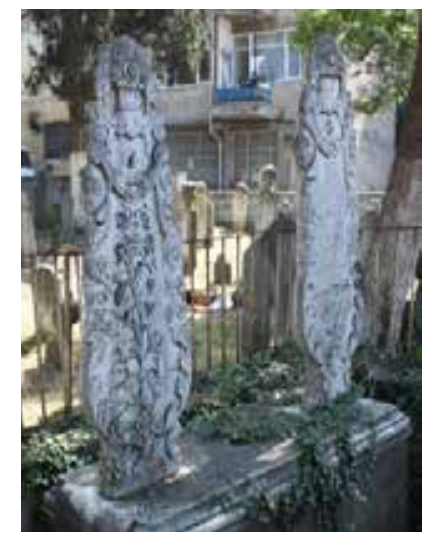

F. 13a

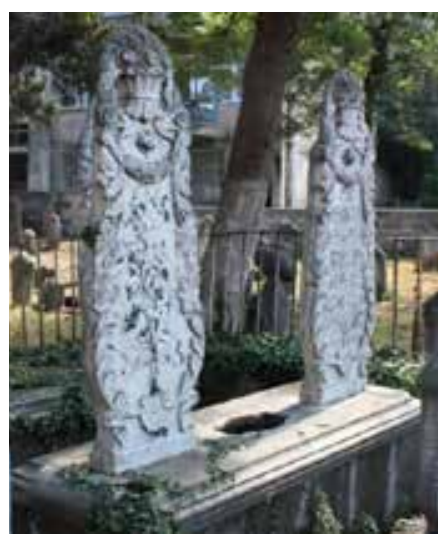

F. 14a

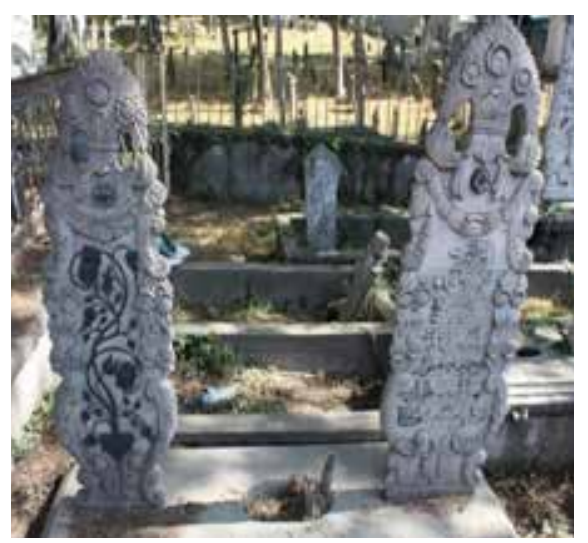

F. 15a

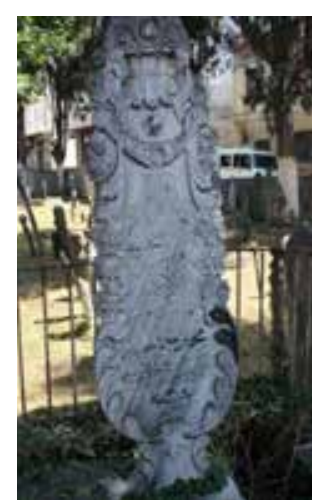

F. 13b

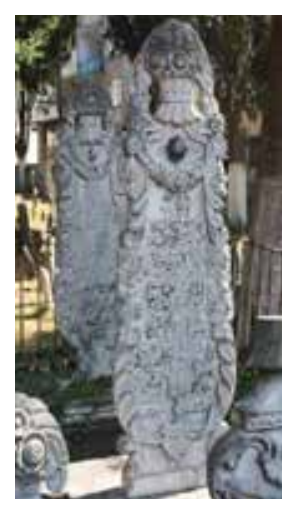

F. 14b

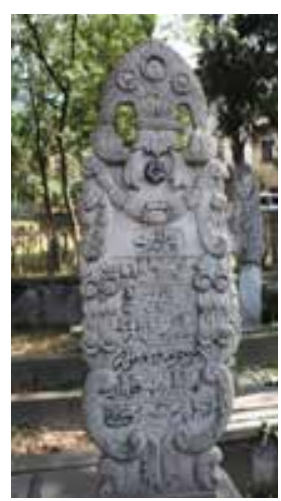

F. 15b 

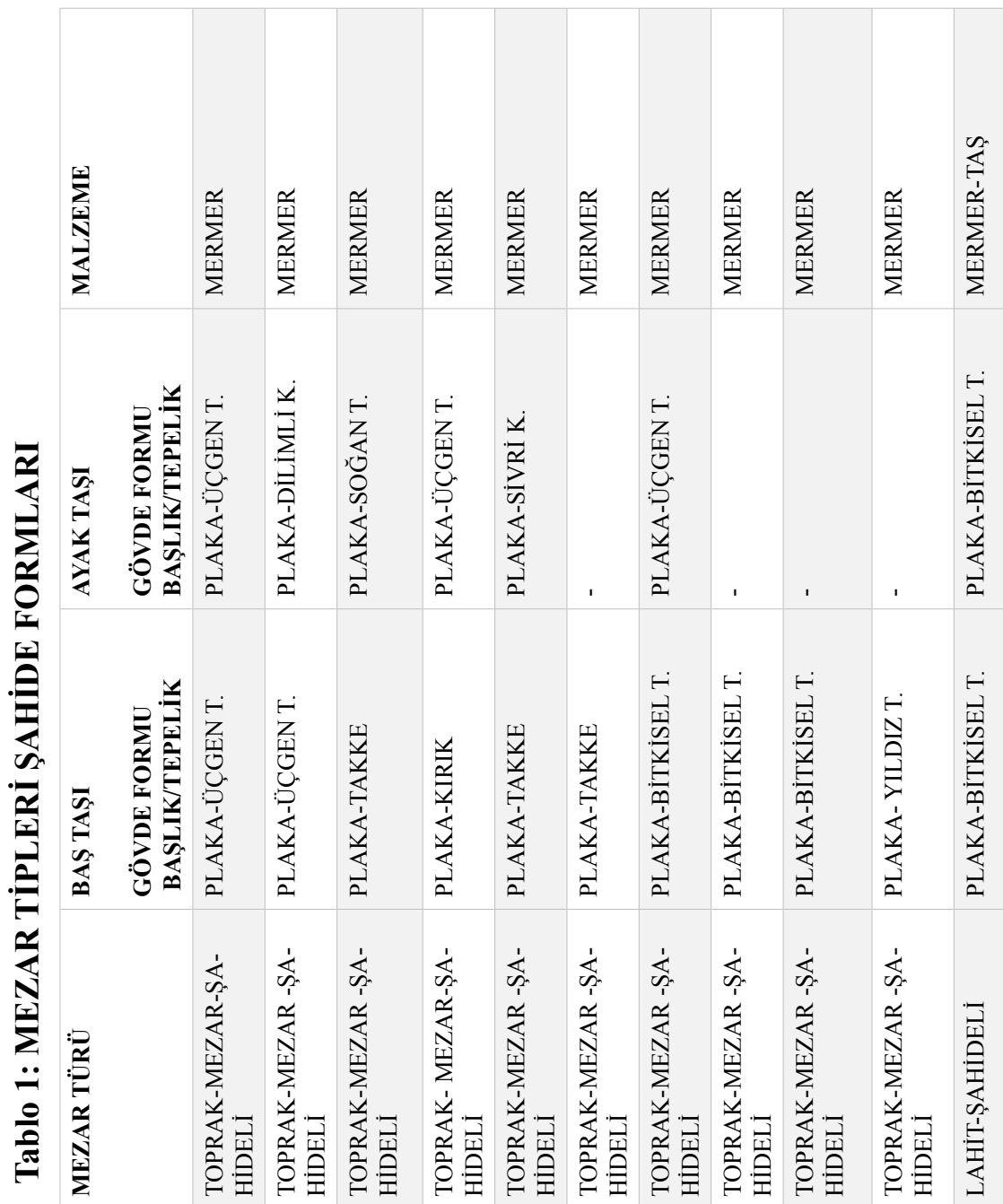

竞芯

\begin{tabular}{|c|c|c|c|c|c|c|c|c|c|c|}
\hline$\frac{\mathbb{x}}{\underline{\varkappa}}$ & 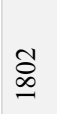 & $\stackrel{\widetilde{\infty}}{\infty}$ & 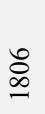 & $\stackrel{\circ}{\circ}$ & 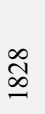 & $\begin{array}{l}\infty \\
\infty \\
\infty\end{array}$ & $\begin{array}{l}\stackrel{\circ}{\infty} \\
\infty\end{array}$ & $\stackrel{\mathscr{D}}{\infty}$ & $\begin{array}{l}\mathbb{\infty} \\
\infty \\
\infty\end{array}$ & $\stackrel{\tilde{\sigma}}{\sigma}$ \\
\hline $\begin{array}{l}0 \\
z \\
0 \\
2\end{array}$ & - & $N$ & $m$ & $\nabla$ & $n$ & 0 & $r$ & $\infty$ & $a$ & 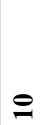 \\
\hline
\end{tabular}


Trabzon Tavanlı Cami Haziresi 19. Yüzyıl Kadın Mezar Taşları
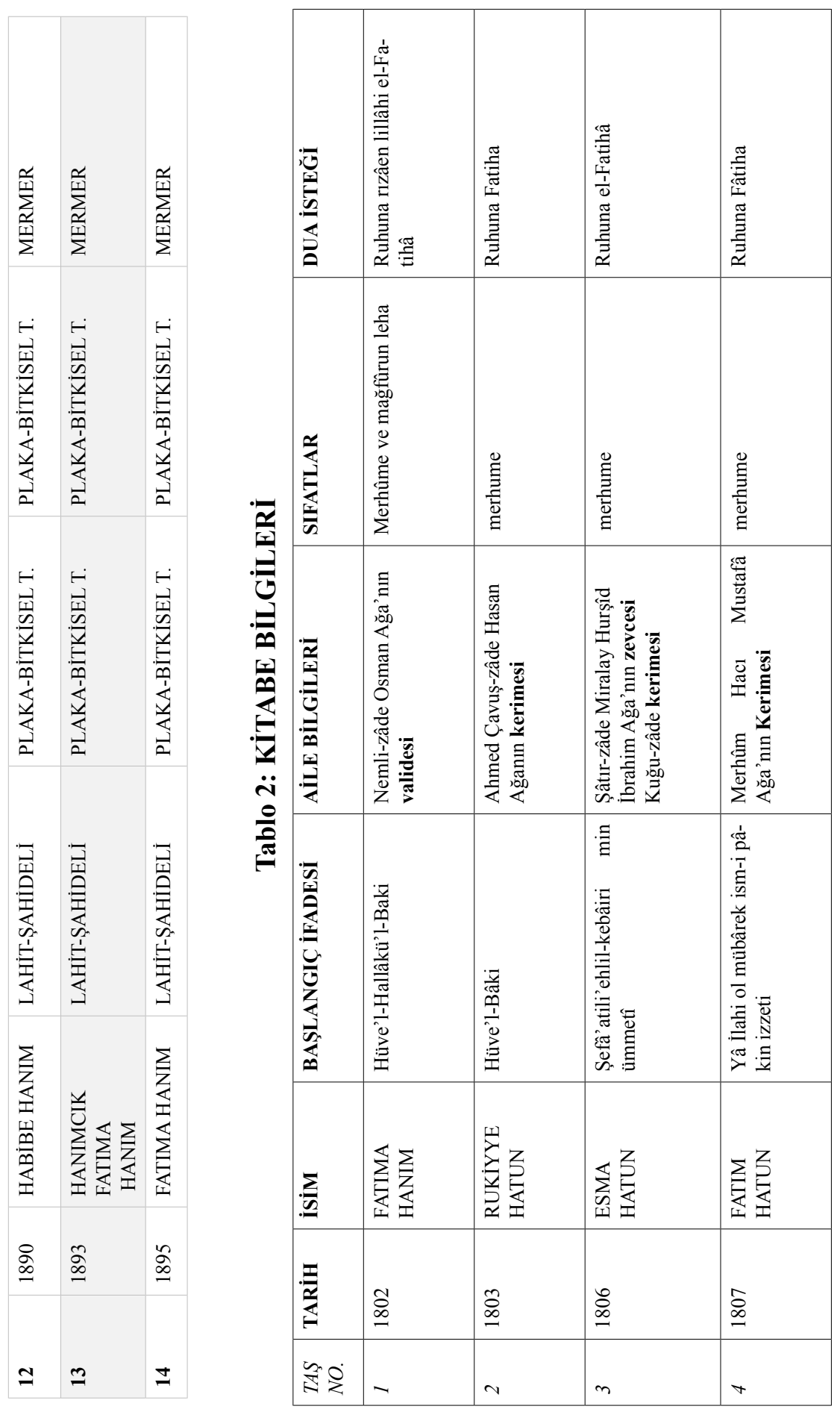


\begin{tabular}{|c|c|c|c|c|c|c|}
\hline 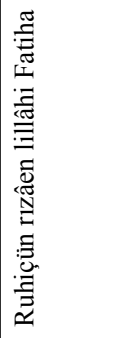 & 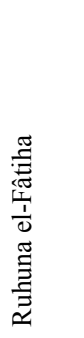 & 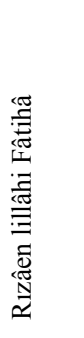 & 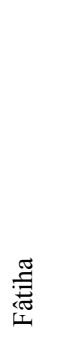 & ' & 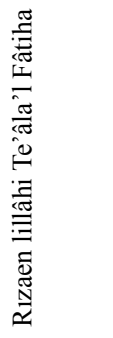 & 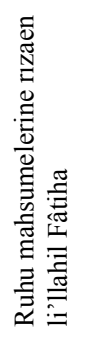 \\
\hline 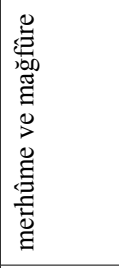 & ' & ' & ' & . & 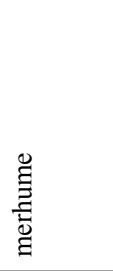 & , \\
\hline 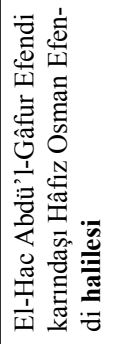 & 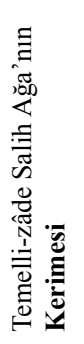 & 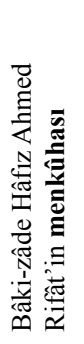 & 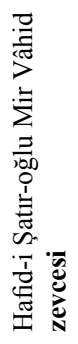 & 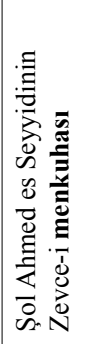 & 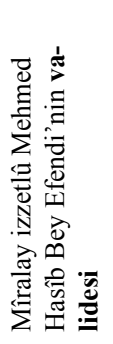 & 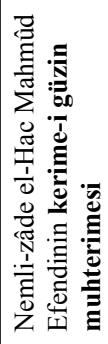 \\
\hline 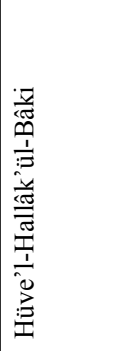 & 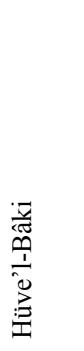 & 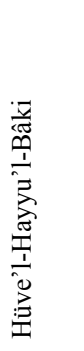 & 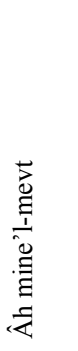 & 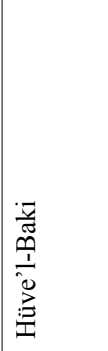 & 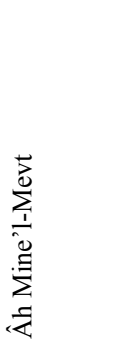 & 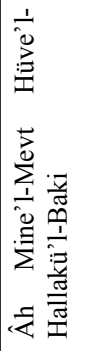 \\
\hline 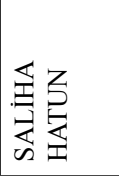 & 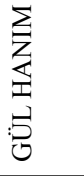 & 焉变 & 空主 & 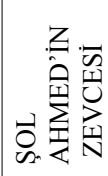 & 空离 & 退齐 \\
\hline $\begin{array}{l}\infty \\
\infty \\
\infty \\
-1\end{array}$ & $\stackrel{n}{\infty}$ & $\mathscr{\infty}$ & $\infty$ & $\begin{array}{l}0 \\
\infty \\
\infty\end{array}$ & $\stackrel{\tilde{\partial}}{\infty}$ & {$\left[\begin{array}{l}\infty \\
\infty \\
\infty \\
-\end{array}\right.$} \\
\hline in & 6 & $n$ & $\infty$ & $a$ & $\approx$ & $\approx$ \\
\hline
\end{tabular}


Trabzon Tavanlı Cami Haziresi 19. Yüzyıl Kadın Mezar Taşları

\begin{tabular}{|c|c|c|}
\hline 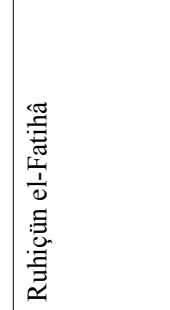 & 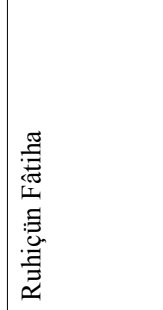 & 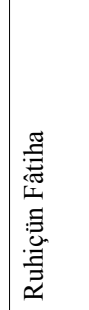 \\
\hline & , & 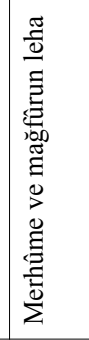 \\
\hline 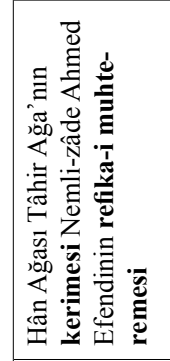 & 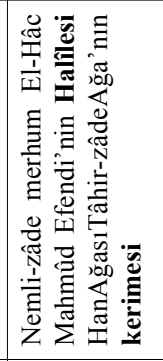 & 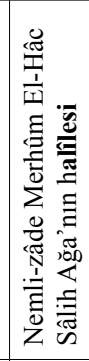 \\
\hline 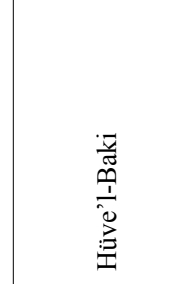 & 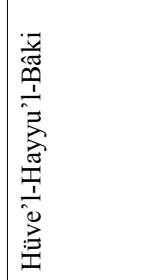 & 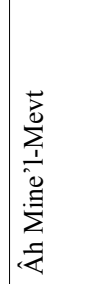 \\
\hline 留亥 & 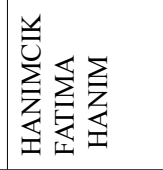 & 离畜 \\
\hline$\stackrel{\triangleright}{\stackrel{\infty}{\rightarrow}}$ & $\underset{\stackrel{\Delta}{\infty}}{\stackrel{t}{\infty}}$ & 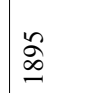 \\
\hline$\approx$ & $\approx$ & $\nexists$ \\
\hline
\end{tabular}

